\title{
Keeping Up with CEO Jones: Benchmarking and Executive Compensation
}

\author{
Ron Laschever* \\ University of Illinois at Urbana-Champaign
}

December 2010

\begin{abstract}
This paper seeks to understand the role that peer comparisons play in the determination of executive compensation. I exploit a recent change in the Securities and Exchange Commission's regulations that requires firms to disclose the peer companies used for determining the compensation of their top executives. Using a new dataset of S\&P 900 companies' choice of benchmarking firms during two fiscal periods (2007 and 2008), I investigate what determines the choice of comparison firms. I find that companies have a preference for choosing larger and higher-CEO-compensation firms as their benchmark. Though I find that companies prefer to choose as their benchmark peers with similar firm characteristics, for CEO compensation, this effect is countered by a preference for firms with higher-than-own CEO compensation. Using the complete map of firms' choices, I implement an instrumental variable strategy that uses the characteristics of peers-of-peers to estimate the effect of others' compensation on own compensation. For Fiscal Year 2007, I find an elasticity of 0.5.
\end{abstract}

Keywords: Executive compensation, peer effects, benchmark, CEO

JEL classification: G3, J33, Z13

*I am grateful to Craig Olson for continuous discussions. I thank Kristine Brown, Igor Cunha, Taekjin Shin and seminar participants at Illinois Wesleyan University, Purdue University, University of Illinois at Urbana-Champaign, University of Oregon, and the 2008 Western Economic Association Meetings for discussions and comments. Taekjin Shin has generously provided the data on board membership. Jim Buel, Joon Yeol Lew, and Amy Shen provided excellent research assistance. This research is supported by a grant from the W.E. Upjohn Institute for Employment Research (\#10-122-02). The findings and conclusions expressed are solely those of the author. All errors are mine. Contact info: Dept. of Economics and School of Labor and Employment Relations, 504 E. Armory Ave., Champaign, IL 61820, USA. Email: ronL@illinois.edu 


\section{Introduction}

Executive compensation has risen considerably since the $1980 \mathrm{~s}^{1}$ and continues to attract attention from shareholders, policy makers, and the public at large. ${ }^{2}$ Anecdotal evidence suggests that firms tend to choose high-compensating firms as their peers. For instance, in a recent New York Times article, Denise L. Nappier, the treasurer of Connecticut and fiduciary of the state's $\$ 23$ billion Retirement Plans and Trust Funds is quoted as saying: "The thing about looking at CEO pay of competitive companies, often companies will want a CEO to be paid in the top quartile of his peers. But not everyone can be above average and this tends to ratchet pay up" (Morgenson, 2006). Piketty and Saez (2003) document that a large part of the increase in income inequality in the US during the last few decades is due to the growing share of wage-earners, such as executives, in the top percentile and 0.1 of a percentile of the income distribution. They suggest social norms regarding pay inequality as one possible explanation for this increase.

Firms may choose higher-paying peers to benchmark against because those firms are more attractive, or because compensation committees may want to give a competitive compensation package to their Chief Executive Officer (CEO). Compensation committee members may also be influenced by a psychological motivation and choose to pay CEOs in comparison to their own pay (as proposed by O'Reilly et al., 1988) or that of other CEOs. Festinger (1954) posited that absent objective measures of ability, individuals will seek to compare to the abilities of others. Similarly, compensation committees might find it hard to evaluate their own CEOs and turn to other firms for best practices.

This paper seeks to understand the role that comparisons and peers play in the continued increase of executive compensation. I exploit a recent change in the United States Securities and Exchange Commission (SEC) regulations requiring companies to disclose the peer companies used for determining compensation. I construct a new dataset of companies' choice of benchmarks for all firms in the Standard \& Poors 900 (consisting of the S\&P 500 and MidCap indices). I investigate what determines the choice of comparison companies and find that firms have a preference for

\footnotetext{
${ }^{1}$ Murphy (1999) documents that S\&P 500 CEO realized pay doubled in real terms between 1980 and 1995. Bebchuk and Grinstein (2005) find that the ratio of top executives compensation to firm earnings grew from $5 \%$ in $1993-1995$ to $10 \%$ in $2001-2003$.

${ }^{2}$ For instance, in 2007, the New York Times (Dash, 2007), ran a seven-page story (which it does annually) on executive compensation. The Committee on Oversight and Government Reform (110th Congress), held hearings regarding CEO pay on December 5, 2007 and March 7, 2008.
} 
including as their benchmark larger (in terms of assets, net sales, and number of employees) firms, and firms that have higher CEO compensation. In addition, I find that firms display an aversion to choosing firms that are dissimilar to them, but that this effect is largely mitigated when firms consider other firms that have higher compensation than their own. I then examine the causal effect of a change in others' pay on own pay using an instrumental variable strategy that makes use of the extensive network mapping that is revealed by firms' benchmark choices.

In 2006, the SEC implemented changes to the required reporting of executive compensation. The amended Final Rule Release was released on August 2006 (Securities and Exchange Commission, 2006). ${ }^{3}$ The purpose of the changes was to increase transparency. ${ }^{4}$ The new release calls for an extended Compensation Discussion and Analysis disclosure. One suggested component is: "whether the company engaged in any benchmarking of total compensation or any material element of compensation, identifying the benchmark and, if applicable, its components (including component companies)" (ibid pp. 29). I exploit this change in regulations that resulted in firms reporting the firms they used for their executive compensation benchmark to construct a new dataset of the lists of benchmarking firms.

Though the SEC regulation increased transparency, there are no actual stipulations regarding how a firm must go about choosing its benchmark. Similarly, there are no direct guidelines as to how the benchmarks and their components should be used in determining executive compensation. Nonetheless, the majority of companies provide some rationale in their proxy statements for how they choose their benchmarks (including the use of compensation consulting firms). Many of the firms then use their benchmark choices to determine own-firm executive pay, either via a simple regression, or more often, using some summary statistic such as the mean or a particular decile. Hence, the choice of benchmark affects CEO compensation. Further, because firms' current-year compensation is used by other firms in their benchmarking, a ratcheting effect could possibly occur.

This paper is related to a growing literature on the determinants of executive compensation.

\footnotetext{
${ }^{3}$ The amended release 33-8732A, a 436-page document is available at http://www.sec.gov/rules/final/2006/338732a.pdf

${ }^{4}$ In a speech given January 23, 2007, SEC Commissioner Roel C. Campos said: "our goal is to make executive compensation as transparent as possible, so that shareholders fully understand what executives are being paid. Further, with our new rules requiring a 'Compensation Discussion \& Analysis' section, it is also our goal to require disclosure of the board's process of setting executive compensation and to have companies explain the board's analysis as to why it settled on the levels of compensation granted." The speech is available at http://www.sec.gov/news/speech/2007/spch012307rcc.htm
} 
Murphy (1999) and Bertrand (2009) provide a comprehensive review of some of the issues, as well as reasons for the growing interest in the topic. This paper is also related to a growing interest among economists in the role of peer effects and social influences. ${ }^{5}$ Antle and Smith (1986) were one of the first to examine the effect of relative performance evaluation on executive compensation. There are several papers that examine the role of relative performance pay. Gibbons and Murphy (1990) examine CEO contracts and find that many firms use relative performance pay as part of compensation. Though relative performance evaluation is somewhat tied to the choice of benchmarks, it is possible for a firm to determine its CEO pay based on the pay of others, without explicitly using any form of relative performance evaluation.

There are also several studies investigating actual proxy statements of firms. For instance, Porac et al. (1999) scan firms' proxies for the use of words such as peers to examine the use of comparable firms. Bannister and Newman (2003) examine proxy statements for use of relative performance evaluation practices. However, these studies are all constrained by the fact that until the recent change in SEC regulations, information on the actual components of each firm's benchmarking is limited. The one notable exception is the work of Faulkender and Yang (2010) who, concurrently with my work, have examined the factors that affect benchmark choices among a sample of S\&P 900 firms in 2007 using the same recent change in SEC regulation. Similar to my results on the determinants of benchmark choice, they find a preference for higher-compensation firms as a benchmark. However, this paper differs on two important dimensions. First, I have an additional year during which to observe firms' choices. I use this to allow for choosing-chosen pairwise fixed effects that control for any fixed unobservable component between every two possible firms. Once these fixed effects are used, the importance of higher-compensation firms is restricted to cases in which choosing and candidate firms are in the same sector. Second, using the complete mapping of choices among the S\&P 900 firms, I implement an IV strategy that examines the causal effects of others' pay on own pay. Since there is no legal or other stipulation tying choice of benchmark to what firms ultimately pay their CEOs, understanding how benchmark composition affects pay has important implications.

To examine the role of CEO compensation in the choice of benchmarking, I first examine the

\footnotetext{
${ }^{5}$ These range from theoretical work on network formation and network games (see Jackson, 2004 for a survey of networks games) to the measurement of peer effects in such settings as welfare take-up (Bertrand et al., 2000), recidivism (Bayer et al., 2009), etc.
} 
factors that make a firm more likely to be included as a benchmark. I find that after controlling for a host of firm characteristics and performance, higher-compensation firms are more likely to be chosen. I then examine the interaction between the choosing and chosen firm characteristics. I estimate a model in which a compensation committee's preferences depend on own-firm characteristics, chosen (benchmark) firm characteristics, and the differences in characteristics between own and benchmark firm. For example, I find that the more firms are different in sales or assets, the less likely they are to be chosen. Though the same holds for CEO compensation, this effect is canceled out by the preference of firms for higher (than own firm) compensating firms. I further investigate the role of both CEO characteristics (e.g., tenure with the firm, whether also chair of board) and board structure (e.g., number of independent board members, number of boards on which each member is serving) in determining the choice of benchmark.

I then use the wealth of information regarding each firm's chosen benchmark and consider an identification strategy that allows me to examine the effect of other's pay on own pay. Since in the case of executive compensation the choice of comparison groups is determined by the firm, any examination of peer effects that fails to take this fact into account will lead to biased results. For example, a firm employing a star $\mathrm{CEO}$, corresponding to a high unobserved (to the econometrician) component, may also be more likely to choose as their reference group other firms with high performing and highly paid CEOs, leading to a correlation between the unobserved component and others' pay. Two features of the benchmarking choice process allow me to overcome the inherent endogeneity of the choice of benchmark and implement an instrumental variable strategy. First, unlike many other group and peer settings, a choice to include one firm in a benchmark does not require the chosen firm to reciprocate (i.e., include the firm that has chosen it in its benchmark). Second, there is ample heterogeneity in the choices of firms, and benchmark choices are not tightly clustered within subgroups. For example, not all large S\&P 500 software firms choose the identical set of firms as their benchmark.

Having the complete mapping of choices among the S\&P 900 firms, I instrument for the pay of a firm's benchmark group. I use the (non-compensation) characteristics of firms that were chosen by firms in that benchmark that are not included in own benchmark. In other words, the benchmarkof-benchmark choices (one-degree-removed) provide the exclusion restriction. The intuition of this identification strategy is similar in spirit to that used in Laschever (2009), and De Giorgi et al. 
(2010). Controlling for own-firm characteristics and firm fixed effects, and implementing the IV strategy, I find that the elasticity of total CEO compensation with respect to the elasticity of their benchmark average pay is between 0.4 and 0.6 , depending on the specification. I further show that the results hold when firms in the same industry are excluded from the benchmark-of-benchmark IV.

The results of this paper suggest that the pay of others plays an important role in determining own pay. This in turn leads to a "social multiplier," as an increase in pay in one firm will have a spillover effect on the firms that use it as a benchmark. Subsequently, those firms further cause the pay of yet other firms to increase, as they are used as part of those benchmarks. Examining the use and consequences of benchmarking can further our understanding regarding some of the causes of executive pay ratcheting. This may lead to more awareness among compensation committees and/or require stricter SEC guidelines on the use of benchmarking. Further, since the use of benchmarking and salary surveys is not limited to CEOs, this paper contributes to our understanding of wage dynamics in other markets. For example, Babcock et al. (1996) show that negotiators for teacher contracts make favorably "biased" choices of other school districts to use as their benchmark.

The rest of the paper is organized as follows. In Section 2, I present the data used in this paper. The empirical framework is discussed in Section 3. The results about benchmark choice are provided in Section 4. Section 5 examines the effect of others' compensation on own compensation. Section 6 concludes and outlines future areas of research. The tables are at the end of the paper.

\section{Data}

The data for this paper are assembled from two sources. The main source is a newly constructed dataset of the benchmarking firm choices collected from the proxy statements of the S\&P 900 firms, roughly representing the largest 900 publicly-traded firms. Benchmark choices were collected twice for each firm, during Fiscal Year 2007 and Fiscal Year (FY) 2008. Following the new SEC regulation, as discussed in Section 1, each firm is required to give more detail on its benchmarking processes. For each company, I collected the names of all the firms it used as a 
benchmark for the compensation of its executives. ${ }^{6}$ The data are collected from the FY 2007 and FY 2008 statements, the first two post-reform years. In addition, I collected the name of the compensation consulting company used by the firm in determining its compensation package. Each of the firms (both choosing and chosen) was then linked and matched with financial information (including its executive compensation) for FY 2006, 2007, and 2008. The financial information, compiled by Standard and Poor's in their Compustat database provides detailed and comprehensive financial information on both the firm financials, and the compensation of the top five executives. ${ }^{7}$ This paper focuses on those designated as Chief Executive Officer or a comparable title.

The financial variables I examine in this paper are based on those commonly used in the executive compensation literature. Most of the empirical specifications focus on total compensation using the SEC definition. This measure includes the base salary, bonus, non-equity incentive plan compensation, change in the value of pension, stock awards, option awards, and all other compensation. This is the measure required by the SEC, and is likely to be the most readily available to other firms. The results using other compensation measures, such as valuing options using grant date fair value, are similar. For example, I find similar results when I examine the "current compensation" measure which consists of only salary and bonus.

The data are summarized in Table 1. The first set of columns reports the measures for the S\&P 500 sample. The second set of columns examines the MidCap sample. The last set of columns includes all 1,753 firms for which financial information was available and total compensation was non-zero. They include almost all of the S\&P 500 and MidCap firms, and many of the SmallCap firms. Though there are thousands of other firms, the choosing firms are all S\&P 500 or MidCap firms that are not likely to be interested in extremely small firms, or likely to use firms for which public information is not available. Many firms explicitly state in their proxies that they omitted from their comparison group firms for which information is not available. In addition, I have manually searched for the compensation details for all firms that were chosen, but were missing information in the ExeuComp file.

As to be expected, in Fiscal Year 2006, the average total CEO compensation among S\&P 500

\footnotetext{
${ }^{6}$ This information is reported in the proxy statement Schedule $14 \mathrm{~A}$ that every company must file annually, and is publicly available at the Security Exchange Commission's EDGAR system accessible at http://www.sec.gov/edgar.shtml

${ }^{7}$ The COMPUSTAT database is available at https://wrds.wharton.upenn.edu/
} 
firms was more than double that of firms in the MidCap index (\$10.5 million vs. $\$ 4.25$ million). In both cases, there is large dispersion, as can be seen by the standard deviation in total CEO compensation: \$10.9 million for the S\&P 500 firms, and \$4.1 million for the MidCap firms.

Following the literature, I use as size controls: assets, net sales, market value, and number of employees. For industry, I use three levels of categorization. The most general one, following Murphy (1999) and others is one of four types: Mining \& Manufacturing, Financial Services, Utilities, and all other industries. The finer level is one of ten 2-digit GICS sectors. ${ }^{8}$ The most detailed level I examined was the 4-digit SIC (Standard Industrial Classification) code.

Throughout this paper, "choosing firm" refers to a firm's information regarding the choice of others, as listed in the choosing firm's FY 2007 and FY 2008 proxy statement. The financial information of the choosing and chosen firms (both for the firm and its executives) is based on the one-year-lagged financial information. I use the lagged financial information because that would be the latest publicly available information for firms making their choice of benchmark for the upcoming year. Examining the lagged measures also reduces the likelihood of a bias due to simultaneity.

In terms of the firms' choices, there is a great deal of variation in the number of firms chosen. ${ }^{9} \mathrm{I}$ dropped firms that did not list actual firm names in their benchmarking list. I also dropped a couple of cases in which the list contained over 400 firms (with more than 2000 firms actually listed in one case). The average length of the benchmarking list is remarkably similar across years. Also, there are no statistically significant differences between the list length of S\&P 500 and MidCap firms. For example, among S\&P 500 firms in FY 2007, the average benchmark list chosen has 21.81 firms with a standard deviation of 17.13 and a median of 17. For the same year, MidCap firms chose a median of 16 firms. In terms of the firms chosen, among the lists generated by the S\&P 500 sample, 1573 firms were chosen at least once, and close to 1000 were named by at least two firms, suggesting that even among S\&P 500 firms, a considerable number of firms choose firms outside their own index. The most popular firm among the S\&P 500 sample is Johnson \& Johnson,

\footnotetext{
${ }^{8}$ The GICS (Global Industry Classification Standard) is maintained by Standard \& Poor's. The ten sectors are: Energy, Materials, Industrials, Consumer Discretionary, Consumer Staples, Health Care, Financials, Information Technology, Telecommunication Services, and Utilities.

${ }^{9}$ I am unaware of any specific guidelines as to the number or nature of benchmark firms a company must choose. This is also evident from the differences in the amount of detail in the proxy statements that firms provide regarding their choices.
} 
which is listed on 60 benchmarking lists. Among the MidCap firms, the most popular choice (19 times) is Ann Taylor.

Table 2 looks at the distribution of choices among choosing firms in the S\&P 500 for FY 2007. The cells along the diagonal designate a case in which the choosing firm is in the same category as the choice along that dimension. Panel A examines CEO total compensation. In $64.1 \%$ of the cases, the choice is made outside of own quartile. Panel B examines industry, and $25.5 \%$ of the choices are made outside of own industry. This distribution of choices suggests firms are more likely to choose outside their own compensation quartile than outside their own industry.

\section{Empirical Framework}

The first empirical specification examines the characteristics that make a firm more likely to be "appealing," as measured by the number of times it is chosen to be included in other firms' benchmark group. Let $y_{j}$ be the number (count) of times a firm $j$ is listed by another firm as a member of its benchmarking group, then a simple reduced-form specification can be written as

$y_{j}=f\left[\alpha+x_{j}^{\prime} \beta+\epsilon_{j}\right]$, where $x_{j}$ are various characteristics of firm $j$, such as its industry or assets, and $\epsilon_{j}$ is the error term. If firms are choosing their benchmarks based on other firms' attributes, then the coefficients for those attributes might be statistically significant. For example, if firms are choosing benchmark-firms that have similar characteristics to their own, and larger firms are choosing other large firms, then the coefficient on firm size, $\beta_{\text {size }}$, might be greater than zero. On the other hand, controlling for firm characteristics and firm performance, executive compensation should not have a statistically significant effect if firms are choosing based on firm attributes, and not the compensation details of its management. The above specification is estimated using various functional forms in Section 4.

Examining the factors that make a firm more likely to be chosen has the appeal of being straightforward. It does not impose any restrictions on which firm characteristics are important or how are they important. It does not restrict firms to choose benchmark-firms that are similar to them. For example, firms might want to include successful firms in their benchmark and might have a preference for those that have performed well, or are industry leaders.

The main shortcoming of the count-specification is that it only controls for the characteristics 
of the choosing firms via the characteristics of the benchmark firms. For example, a finding that firms are more likely to be chosen in a certain industry might be due to the fact that the industry happens to have more choosing firms. Hence the findings on firm characteristics depend on the distribution of firm characteristics among those choosing and the available choices. ${ }^{10} \mathrm{~A}$ similar concern involves the fact that each firm is free to choose as many firms in its benchmarking list as it wants. If firms of different characteristics choose lists of different lengths, then results may be biased. However, my examination reveals that the size of the benchmarking list does not seem to depend on any of the observable firm characteristics. In the above specifications, firm attributes and characteristics should be viewed as controls, and the focal question is whether, all else equal, measures of executive compensation affect the likelihood a firm is included in a benchmark.

\subsection{Utility-based framework of benchmark choice}

Though an examination of the characteristics of the chosen firms indicates the preferences of the choosing firms, one would ultimately want to learn how the characteristics of the choosing firms affect their choices. Benchmark choices are decided by the compensation committee. The committee may have multiple goals in choosing the CEO's benchmark. On the one hand, it might seek to include higher-compensation firms, either due to CEO influence, or as a way to retain and attract management talent. On the other hand, the committee may be constrained in their choices for two reasons. They might want to choose similar firms (say in terms of industry and scope) as part of their professional duty. Further, their choices, being public, are subject to shareholder's scrutiny.

To examine the effect of the various trade-offs committees face, I employ a utility-based choice framework (McFadden, 1974) and focus on how the characteristics of the choosing firm affect its committee's choice of benchmark-firms in terms of CEO compensation. The compensation committee of firm $i$ therefore seeks to maximize the latent utility examining the $j=1 . . J$ available choices:

$$
\operatorname{Max}_{\left\{d_{i, 1}, d_{i, 2} \cdots d_{i, J}\right\}} U_{i}^{*}=\sum_{j=1}^{J} d_{i, j} \cdot u_{i, j}^{*}
$$

\footnotetext{
${ }^{10}$ If firms are choosing assortatively and the number of firms is evenly distributed across the various characteristics, then the coefficient $\beta$ of those characteristics may still be zero. For example, if there are only two types of firms, small and large, and there is an equal number of large and small choosing firms, then the likelihood of being chosen should not depend on size (assuming the number of available choices is also the same).
} 
where $d_{i, j}=I[$ Firm $j$ is chosen by Firm $i]$. Given that there are no guidelines or stipulations for how many firms should be in a benchmark, nor is there any constraint on a firm $j$ being chosen by any or all firms, the committee's maximization problem amounts to examining each firm and choosing those for which the utility from choosing that firm is greater than a certain threshold:

Choose firm $j$ if $u_{i j}^{*}>c_{i}$

Allowing $c_{i}$ to differ across firms allows different firms to have a different threshold for choosing firms and would capture any choosing-firm-specific characteristics.

To capture the fact that compensation committees might be subject to multiple goals, I specify a latent-utility function in which committees consider both their own characteristics, the candidate firm's characteristics, and a possible interaction between their own and the candidate firm's characteristics (the function $h()$ ):

$$
u_{i, j}^{*}=\alpha+X_{i}^{\prime} \beta_{1}+X_{j}^{\prime} \beta_{2}+h\left(X_{i}^{\prime}, X_{j}^{\prime}\right) \beta_{3}+\epsilon_{i, j}
$$

The committee's choice depends on own firm characteristics (the vector $X_{i}$ ), the firm being chosen (the vector $X_{j}$ ), and an interaction between their own and the chosen firm's characteristics (the function $h$ ). For example, a committee might find a high-compensating firm to be attractive, or might want to choose a firm that has exhibited high profits. It may however be restricted to choosing firms in its own industry, or be penalized for choosing a firm that is very different in its compensation levels, as captured by the function $h$.

In the case in which $c_{i} \neq 0$, the own-firm characteristics are captured by this term, and the econometric specification of the committee's decision $d_{i, j}$ of firm $i$ including firm $j$ in its benchmark is:

$$
\operatorname{Pr}(\text { Firm } i \text { chooses firm } j \mid i, j)=\operatorname{Pr}\left(u_{i, j}^{*}>c_{i}\right)=f\left(\alpha+X_{j}^{\prime} \beta_{2}+h\left(X_{i}^{\prime}, X_{j}^{\prime}\right) \beta_{3}+c_{i}\right)
$$

Being able to observe firm choices over two periods, I examine a first-difference that allows for a choosing-chosen pair-specific fixed effect, $c_{i j}$. This specification has the appeal of capturing not only choosing-firm and chosen-firm fixed unobservables, but also control for any pair-wise effect. 
For example, a certain compensation committee board member in firm A may want to include firm B in its benchmark not because of any observable feature, but because she or he have an interest in firm B, or may actually be an executive at firm B. The source of identification in this specification is based on changes between the two fiscal years. For example, does a firm that raises its CEO compensation become more likely to be chosen by other firms controlling for the likelihood it was chosen in the previous year.

I conclude this section by noting a unique feature of the choice problem considered in this paper. The decision to include a firm as a benchmark has no direct effect on the availability of that benchmark-firm to be used as a benchmark by other firms. Also, firms can choose as many firms as they want, and a choice made by one firm has no effect on the ability of another firm to use that very same firm in its benchmarking list. Unlike the usual choice problems in which a purchase of goods affects the equilibrium price, there are no equilibrium or cross-effects in this case. This feature of the setting allows one to estimate the model with no need to account for an equilibrium effect, and instead focus on the choice of every firm separately. ${ }^{11}$

\subsection{Identification and estimation of the effect of others' compensation}

The examination of benchmark choice suggests that own-compensation of executives may depend on the compensation of other CEOs. However, given that this choice is endogenous, one cannot directly estimate the effect of others' compensation. The detailed information on the benchmarking choices of each firm allows me to use an identification strategy that can be implemented using an instrumental variable approach. The approach I use relies on using characteristics of peers-ofpeers as an exclusion restriction. This identification strategy is similar in spirit to that formally discussed and implemented in other settings by Laschever (2009) and De Giorgi et al. (2010), who examine employment and choice of college major, respectively. Similar to those papers, I exploit the network structure and the exclusions it generates.

The reduced-form relationship between others' compensation and own compensation for each

\footnotetext{
${ }^{11}$ Hayes and Schaefer (2007) present a game-theoretic model in which they assume firms set high CEO pay to increase the external perceptions of their firm's value.
} 
CEO and firm $i$, in year $t$, can be written as:

$$
C E O \_p a y_{i, t}=\alpha+X_{i, t}^{\prime} \beta_{2}+\rho \cdot M\left(C E O \_ \text {pay }_{t-1} \text { of firms in benchmark } k_{i}\right)+\epsilon_{i, t}
$$

where $X_{i}$ are firm and CEO characteristics that may influence pay, including controls for industry, and S\&P index. The function $M$ summarizes the compensation of all firms chosen by firm $i$ as their benchmark. In the empirical specification I will examine both the effect of the average compensation among the benchmark firms as well as different deciles. The interpretation of the coefficient $\rho$ would be consistent with the effect of others' pay on own compensation.

There are at least two types of reasons as to why others' pay, $M\left(\right.$ benchmark $\left._{i, t-1}\right)$, might lead to biased results. First, the choice of benchmark is endogenous. For example, a firm employing a star CEO, corresponding to a high unobserved (to the econometrician) $\epsilon_{i}$, may also be more likely to choose as their reference group other firms with high performing and highly paid CEOs leading to a correlation between $\epsilon_{i}$ and $M$ (benchmark $\left.k_{i, t-1}\right)$. Second, if any of the firms in the benchmark of firm $i$ included firm $i$ in their own benchmark, the usual simultaneity problem would arise.

I focus on the lag compensation of others as it is more consistent with the institutional setting, as firms would only know other firms' lagged financial details. In addition, there are two main advantages of using $M\left(\right.$ benchmar $\left.k_{i, t-1}\right)$, the lag-pay of others: it no longer requires me to make the assumption that firms (correctly) anticipate the pay of other firms, and it reduces the simultaneity problem of the group decision. ${ }^{12}$ However, the use of a lag does not eliminate the simultaneity problem. For example, if there is an important observable or unobservable factor that affects CEO pay, it might also affect previous-year compensation as strongly as it affects (planned) currentyear compensation of others. The results remain similar when contemporaneous pay of others is considered, and it is important to note that the use of lags is not the source of identification.

From the reduced-form specification it is apparent that if the choice is endogenous to pay, one cannot estimate this relationship without a proper exclusion restriction. The identification strategy used in this paper is to use the characteristics (such as sales and number of employees) of the firms that were chosen as benchmarks by firm $i$ 's benchmark firms (i.e., peers of peers) as an instrumental variable. This is illustrated by a stylized diagram in Figure 1. The left-hand dashed ellipse maps

\footnotetext{
${ }^{12}$ See Angrist and Pischke (pp. 194-198, 2008) for a concise treatment of the drawbacks to using same-period outcomes of others.
} 


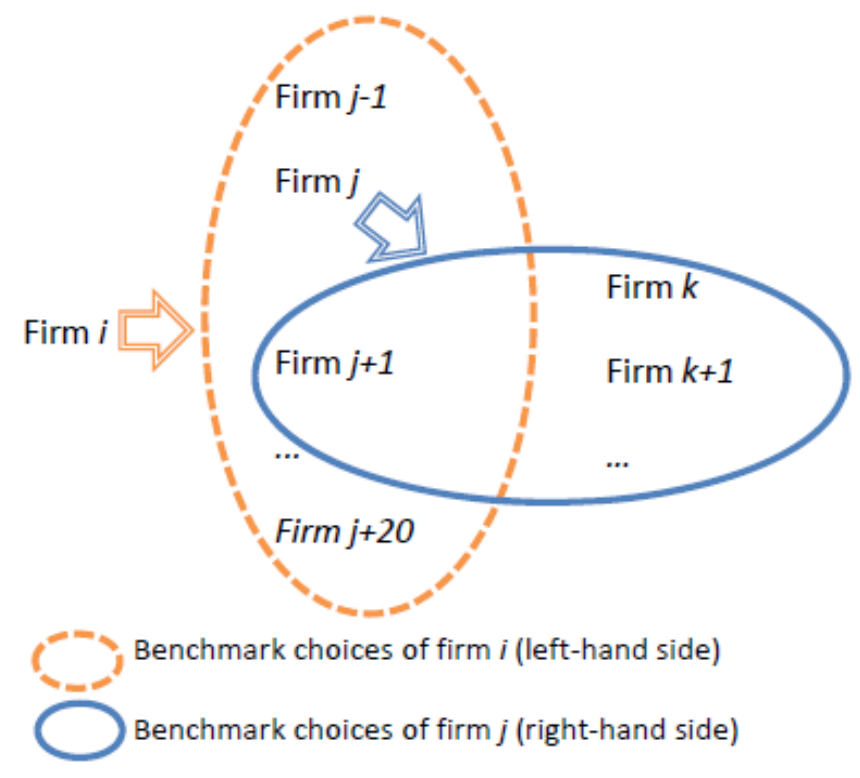

Figure 1: Diagram of benchmarking choices

the choices made by firm $i$ which includes firms $j-1$ through $j+20$. The right-hand ellipse maps the choices made by firm $j$, which possibly may include an overlap with the choices of firm $i$ (e.g. firm $j+1)$. In this particular case, the characteristics (not pay) of firms $k, k+1, \ldots\left(X_{k}, X_{k+1}, \ldots\right)$ will be used as an instrumental variable for the CEO pay of firm's $i$ benchmark (i.e. the CEO pay of firms $j-1, \ldots j+20)$.

Note that figure 1 omits the benchmarking choices of firms $j-1, j+1,1, . . j+20, k, k+1 \ldots e t c$. Those choices may further exclude other firms from being included as an instrument. For instance, if firm $j+1$ chooses firm $j+20$ in its benchmark, $j+20$ cannot be used, as it is also directly chosen by firm $i$. Also, a firm $k$ is not included if it chooses firm $i$ in its benchmark. Formally, the instrumental variable is therefore defined as:

$$
\begin{aligned}
I V \text { Set for firm } i \equiv & \{\text { All Firms } k \mid i \text { is not chosen by } k \text { and } \\
& \text { for all } j \text { chosen by } i, k \text { is chosen by } j \text { and } k \text { is not chosen by } i\}
\end{aligned}
$$

This identification strategy is related to the formal treatment that can be found in Laschever (2009) and De Giorgi et al. (2010). The validity and performance of this instrument is further discussed in Section 5. However, it is worth noting that relative to other cases in which network structures 
are formed and in which ties might go both ways (for example, friendships might depend on both sides agreeing to a relationship), here a firm may choose as many other firms as it wants, at no cost. Further, the firm is not likely to have any direct advantage to choosing a benchmarking firm based on that benchmarking firm's benchmark. Whereas in the case of friendships, agents might choose friends based on the utility gained from being part of their friend's network (friends of friends), this is not likely to be true for benchmarking. Choosing a benchmark firm does not impose any obligations on the chosen firm to choose back the same firm.

Finally, from an estimation standpoint, the mapping of choices must generate sufficient variation in the benchmark lists and exclusions of each firm. For example, if all firms in an industry chose the same exact set of firms, or if firms formed exclusive groups and made choices only among group members, one could not hope to use this approach. However, as discussed below, while there is a good amount of overlap in choices (as to be expected) there is a sufficient number of cases in which firms chose outside the choice-set of the firm that chose them.

\section{Results}

\subsection{Factors that affect the likelihood of being picked}

In this section, I examine the factors that affect the likelihood that a firm is chosen to be included in another firm's benchmarking list. The set of choices includes all of the 1,753 firms in the 2006 Compustat file. As explained in Section 2, this is likely to be very similar to the set from which firms can choose, as firms tend to omit from their benchmarking lists peers with no publicly available data, and I have manually added any executive compensation data missing from those firms chosen. The constructed count measure is the number of times a firm was included as a benchmark firm by each of the S\&P 500 or MidCap choosing firms in the sample. For firm $j$, the count measure is:

$$
y_{j, t}=\sum_{k=1 . . K} \text { firm } j \text { is included in firm } k \text { 's benchmark group during fiscal year } t
$$

For those chosen, this count ranges from 0 to 60 , and more than 1500 firms are chosen by at least one firm (see Section 2). 
I estimate the factors affecting the number of times a firm is chosen. As explained in Section 3 , though I am examining the complete sample of choosing firms, since the distribution of various firm characteristics is not uniform, it is important to control for various firm characteristics, such as size and industry. Table 3 provides the first set of results for the dependent count variable constructed for all choosing firms in the S\&P 500 sample (the chosen firms are not constrained to a particular index). The first five columns focus on the choices made during FY 2007 and the last column adds FY 2008. All other measures use lagged (FY 2006) information, to minimize the endogeneity of the decision, and since this is likely the available data that firms had regarding their competitors.

Column 1 examines an OLS specification controlling for sales, number of employees, market value, assets, 1-year and 3-year returns to stockholders, S\&P index (SmallCap, MidCap, S\&P 500, Other), and one of ten sectors (at the 2-digit GICS level). Total CEO compensation of a firm is found to have a sizable and statistically significant effect at the $p<0.01$ level. All else equal, higher-compensating firms are more likely to be included in the benchmark lists of other firms. With the exception of number of employees, 1-year stock returns, and one industry dummy, all other measures are found to be statistically significant at the $\mathrm{p}<0.1$ level or better. Firms with more assets, and those part of the larger indices are more likely to be chosen. Firms in the S\&P 500 are more likely to be chosen. This is not all that surprising given that all of the choosing firms are in the S\&P 500. The R-squared of 0.64 suggests that these measures explain a sizeable portion of the variance in the count. Because the count variable is truncated at zero, column 2 provides the linear tobit (left-censored) estimates. The statistical significance and magnitude of the estimates remain very similar. The point estimate for the CEO compensation measure is now only slightly larger.

The discrete nature of the dependent count variable suggests that a poisson-type regression is more appropriate. The qualitative results as well as the statistical significance of the coefficients remain the same (not reported). The poisson regression is estimated assuming a zero dispersion (that is, the underlying mean and variance are the same). I reject this specification at the $\mathrm{p}<0.0001$ level, and proceed throughout this section to estimate the count data using the more general negative binomial specification. Columns 3 through 6 allow the dispersion factor to vary across the sample. The results are presented in column 3 , and the qualitative results as well as the statisti- 
cal significance of the coefficients remain the same for most of the variables. Once again, higher compensating firm are more likely to be chosen. ${ }^{13}$

The results in column 3 of Table 3 are not only statistically significant, but are of economic importance. For example, the point estimates suggest that all else equal, a firm that pays in the 75 th percentile (as computed using the S\&P 500 sample) will be chosen as a benchmark by an additional 0.25 firms compared to a firm paying the median (as computed using the S\&P 500 sample). When considering the entire sample (which includes the compensation of all firms, including SmallCap firms), a firm paying in the 75 th percentile will be chosen by an additional 0.66 firms compared to a firm paying in the 25 th percentile. For this sample, even conditional on a firm being chosen more than once, the median firm is chosen only 3 times by an S\&P 500 firm. Hence, the findings for the effects of CEO pay are quite sizable.

Columns 4 of Table 3 adds both the CEO's age and years of tenure as the firm's CEO. Both of these personal characteristics are found to be statistically significant throughout the specifications. Older CEOs are more likely to be picked, as are CEOs with less tenure. These results are consistent with firms preferring to use Older CEOs as their benchmark, as they might be more renowned, and newer CEOs, as they might have higher starting compensation packages. Column 5 includes the chosen firm's "Corporation Admired Score" (ranging from 3.09 to 8.7) as computed by Fortune Magazine (2007). ${ }^{14}$ Interestingly, controlling for all other factors, this reputation score is found to have a statistically significant effect at the $\mathrm{p}<0.05$ level. All else equal, an additional point in this score causes a firm to be chosen by 0.35 additional firms. The reputation score remains significant throughout many specifications.

The last column of Table 3 examines the choices of firms over two years, adding FY 2008 choices (firms choices are aggregated separately for each year), and including a year fixed effect. Similar results (not reported) hold when only FY 2008 is examined. The results remain similar both quantitatively and qualitatively, suggesting the results cannot be explained as a one year anomaly. The coefficient on the year dummy is not statistically significant.

Taken together, the results for the S\&P 500 choosing sample suggest that higher-compensating

\footnotetext{
${ }^{13}$ Note that the compensation measure is scaled using log throughout the rest of the table, though similar results are obtained when levels are used.

${ }^{14}$ America's Most Admired List, 2007. Fortune Magazine, March 19, 2007. Firms not selected for the list, were assigned an arbitrary score of 3 . Though the results remain the same if those firms are excluded.
} 
firms are more likely to be chosen. Table 4 examines the same determinants of firms being chosen, using the benchmarking choices of firms in the MidCap index. The results are very similar both quantitatively and qualitatively for the effect of compensation and most other measures. Personal characteristics, as captured by age and tenure lose much of their significance. The point estimates suggest that MidCap firms have an even stronger preference for high-compensating peers. In comparison to S\&P 500, firms in the MidCap index have a preference for choosing firms within the MidCap index. The point estimate across the specifications are very similar.

The results presented in Tables 3 and 4 focus on the total compensation of the chosen firm. I obtained similar results when using other measures of CEO compensation such as salary only, or salary + bonuses only. ${ }^{15}$ The results presented in this section suggest that firms both in the S\&P 500 and MidCap samples during FY 2007 and FY 2008 are more likely to choose firms that provide a higher level of CEO compensation.

\subsection{The linkage between characteristics of choosing and chosen firms}

The findings in the previous section are consistent with firms preferring to include higher CEO compensation firms in their benchmark. However, it focused only on the firms chosen. Although the choosing firms are indirectly included via the use of various industry and firm-characteristics controls, it is of use to directly examine the interaction of the characteristics of the firms choosing and their choices. Following the discussion in Section 3.1, I estimate an equation of the form:

$I($ Firm $i$ chooses firm $j$ in FY $t \mid \cdot)=f\left[\alpha+X_{i, t}^{\prime} \beta_{1}+X_{j, t}^{\prime} \beta_{2}+\operatorname{distance}\left(X_{i, t}^{\prime}, X_{j, t}^{\prime}\right) \beta_{3}+\theta_{t}+c_{i, j}\right]$

where $I()$ is an indicator function equal to 1 if firm $j$ is chosen and 0 otherwise, $X_{i}$ are the characteristics of the choosing firm, and $X_{j}$ are the characteristics of a prospective firm $j$ considered to be included in the benchmark. The estimation considers every possible pair of choosing-firm $i$ and candidate-firm $j$.

The results in Table 5 examine the linear probability functional form $(f(w)=w$ in the above equation). The first column only includes the characteristics of the candidate firm. As to be expected, since the main difference is the functional form, the results are similar in nature to those

\footnotetext{
${ }^{15}$ These results are available upon request from the author.
} 
presented in the previous section, such as larger firms are more likely to be chosen. In particular, the measure of CEO total compensation is found to have a positive and statistically significant effect at the $\mathrm{p}<0.01$ level. Column 2 adds choosing-firm characteristics (corresponding to $X_{i}$ in the above equation) to address the fact that the distribution of choosing firms is not uniform. The results for the coefficients on candidate variables remain almost identical. In column 3, I add dummy variables for each one of the top-5 consulting companies, that were used by the firms to determine their benchmarking lists. These five consulting companies were used by $72 \%$ of the firms, though I obtain similar results are obtained when I examine the top 12 consulting companies. Several of the consulting company coefficients are statistically significant, and they are jointly significant with an F-value of 2.15, suggesting different consulting companies may have different approaches to constructing benchmarks. However, the overall results do not seem to change, and the differences among consulting companies do not seem to be consistently related to firm compensation levels.

To focus on the role of relative comparisons, the rest of the table includes measures of the difference between choosing-firm and benchmark-firm characteristics. Column 4 of Table 5 includes no choosing-firm characteristics. The choosing firms measures are fairly similar to the previous specifications, suggesting a preference for larger and higher-compensating firms. The specification also includes the log of the difference (in absolute value) in assets, sales, number of employees, market value, and CEO compensation between the choosing and benchmark firms, as well as whether the choosing and candidate firm are in the same industry or index. With the exception of compensation, the distance measures are statistically significant at the $\mathrm{p}<0.01$ level and in all but one case are negative in sign, suggesting that firms incur a penalty the more a benchmark firm is different than the choosing firm. Similarly, firms are more likely to choose firms in their own $\mathrm{S} \& \mathrm{P}$ index, and firms in the same industry. For example, being in the same industry increases the likelihood a firm is included in a benchmark by 4.08 percentage points.

Columns 5 and 6 in Table 5 include choosing-firm fixed effects (corresponding to $c_{i, j}=c_{i}$ in the above equation). The fixed-effects capture any relevant firm-choosing characteristics that do not vary across the choices of a given firm. Though the measure of fit increases, the point estimates of many of the variables, including total CEO compensation, are almost identical. The results in column 5 suggest that, similarly to column 4, a firm's utility decreases when choosing a firm that is different than itself. This is also true for compensation. 
The last column includes two CEO compensation measures. The first is the difference in absolute value of CEO compensation. The second is the difference in CEO compensation multiplied by whether the chosen benchmark firm is higher paying than the choosing firm. Both measures are statistically significant at the $\mathrm{p}<0.01$ level, and of opposite signs (in many of the specifications, the point estimates are quite close in magnitude). The results are consistent with firms avoiding potential benchmark-firms that pay very differently, as long as those firms pay less than the choosing firm. On the other hand, choosing a higher compensating firm almost completely counters the negative effect of choosing a differently-compensating firm. For example, the point estimates in column 6 suggest that $70 \%$ of the aversion to different-paying firms is eliminated when the firm considered is higher-paying than own firm.

The size of both the choosing sample and the number of possible choices generate a large sample of possible combinations (almost 1,400,000). To reduce the risk of obtaining statistical significance due to large samples, I examined subsamples of only S\&P 500 combinations (both for choosing and chosen) and only MidCap combinations. The results, available upon request, for the two subsamples, and in comparison to the entire sample, are very similar both qualitatively and quantitatively. Finally, note that all of the specifications in Table 5 include clustering of the error terms across choosing firms, allowing for a correlation between $\epsilon_{i, j}$ and $\epsilon_{i, j+l}$, for two candidate firms $j$ and $j+l$, each being considered by the same benchmark firm $i$.

Taken together, the results in this section suggest that firms have a preference for larger and higher-compensating firms. Firms are less likely to choose other firms that are not in their industry or S\&P index. They are also less likely to choose a firm the more its characteristics differ from theirs, as measured by sales, assets, number of employees, and CEO compensation. However, in the case of CEO compensation, firms exhibit a preference for firms that compensate their CEO higher than the $\mathrm{CEO}$ of the choosing firm. This preference cancels most of the aversion to choosing firms of different CEO compensation. In turn, the results imply that firms could potentially choose others with as high of CEO compensation as they would like, with little if any "penalty" to the utility of the compensation committee.

The inclusion of choosing-firm fixed effects in the above specification only controls for firm unobservables that are the same regardless of which candidate firm is being considered. For example, the same compensation committee of firm A might have very different views about including 
firm B or firm $\mathrm{C}$ in their benchmark, not based on observable information such as market size, but because firm B's CEO is a member of firm A's compensation committee, or because both firms $\mathrm{A}$ and $\mathrm{B}$ are competing in the same product market. Having choice data for two fiscal years, I control for any choosing-firm, candidate-firm, and choosing X candidate fixed effects. The results are presented in Table 6. The dependent binary variable in all specifications is whether or not firm $i$ chooses candidate firm $j$ for its benchmark. The first three columns include only choosing-firm fixed effects and year fixed effects. As before, firms have a preference for larger firms (in terms of workforce and market value). Columns 2 and 3 add choosing-firm characteristics, as they now vary across year. Column 3 conditions on firms that did not experienced CEO turnover. The results of both columns 2 and 3 remain very similar to that of column 3.

Columns 4-6 of Table 6 include choosing-firm, candidate-firm, and choosing-firm X candidatefirm fixed effects. The effect of candidate-firm compensation is now very small and not statistically significant, whereas market value remains statistically significant. Columns 4 and 5 do not include a time trend, and show the results cannot be explained away by a time trend. Finally, in column 5 and 6, I examine the interaction of CEO pay, and whether the choosing firm and candidate firm are in the same industry. The main effect, total compensation, is no longer statistically significant, but the interaction term is positive and statistically significant at the $\mathrm{p}<0.01$ level or better in both cases. Column 6 considers the same specification as column 5, but includes also firms that have experienced CEO turnover. The results in Table 6 suggest that even after controlling for any pairwise unobservable fixed effect, firms have a preference for higher-compensation peers, but that this effect is limited to firms within own sector.

\subsection{Corporate governance measures}

A large literature on the role of corporate governance has found that executives' personal characteristics as well as the board of directors affect executive pay. ${ }^{16}$ To further investigate the underlying mechanism behind the preference for higher compensation benchmarks, I use board membership data and CEO personal characteristics and examine whether board composition has a differential

\footnotetext{
${ }^{16}$ See Finkelstein et al. (2009) for an overview of many of the studies and examined topics.
} 
effect on the manner in which benchmarks are chosen. ${ }^{17}$

Table 7 summarizes the results of a specification corresponding to column 4 in Table 5, including controls for choosing firm, benchmark candidate firm, the differences between the firms, and choosing-firm fixed effects (columns 2-8). I find that CEO age, CEO tenure, and board composition measures have a statistically significant effect on the benchmark choice. However, I find little evidence that either CEO or board characteristics have a statistically significant effect on the likelihood of choosing higher-paying benchmarks. The two notable exceptions are firms whose directors are members in more boards, and firms with CEOs who have less tenure. Such firms have a higher likelihood of choosing higher paying benchmarks.

The first column of Table 7 does not include a choosing-firm fixed effect. I find that firms with CEOs who are also the chairperson of their board are more likely to choose higher-paying benchmarks. However, once choosing-firm fixed effects are included in the specification (column 2) the result becomes much smaller, and is no longer statistically significant, further highlighting the importance of controlling for firm fixed effects. Column 3 examines the interaction of the choosing-firm CEO's years of tenure and the benchmark firm's CEO pay. The statistically significant result at the $\mathrm{p}<0.01$ level suggests that the effect is small and negative. In other words, all else equal, firms with newer CEOs have a preference for higher paying benchmarks, perhaps due to the fact that newly appointed CEOs are more likely to enjoy higher and more competitive salaries as pay levels rise overtime.

In column 4, I include a constructed measure of the average number of other boards (excluding own board) on which the board members of the choosing firm sit on. The results suggest that additional board membership causes the firm to be more likely to choose higher compensation peers consistent with either increased burden on board members, or exposure to more firms and their pay practices. Various specifications (e.g., column 5) suggest that having more non-independent board members (who cannot serve on the compensation committee) does not have a statistically significant effect on the likelihood of choosing a higher-compensation benchmark. The results shown in columns 2-5 hold when the measures are considered together (columns 6-8). Finally, column 8 shows that larger boards have a tendency to choose higher compensation peers, but the effect is not

\footnotetext{
${ }^{17}$ Board membership data were collected by the Investor Responsibility Research Center (IRRC), now part of RiskMetrics.
} 
statistically significant in most of the specifications examined.

\section{The effect of other CEOs' pay on own-CEO pay}

The results presented in the previous section suggest that firms have a preference for including higher-compensation firms as their benchmarks. However, since there are no rules or SEC guidelines as to how to use one's benchmark, it is of interest to examine how the compensation of other CEOs directly affects own-CEO compensation. As discussed in Section 3.1, the reduced-form compensation regression estimates the link between CEO pay and firm and CEO characteristics such as firm size and industry, and the CEO's tenure and age. The main focus of this section is estimating the effect of benchmark firms' CEO pay on own CEO pay.

The first set of results are presented in Table 8. These specifications all use a linear-probability model, and in all cases the dependent variable is the log of the CEO's total compensation. The table includes all S\&P 900 firms (in 2007) that have made a benchmark choice in FY 2007 or 2008 and have available financial data. ${ }^{18}$ The first column of Table 8 estimates the determinants of CEO pay including own firm and CEO characteristics. The findings are consistent with that reported in other studies examining CEO pay (see Bertrand (2009) for a review of the findings). For example, there are positive and statistically significant effects in conventional levels for larger firms (both in terms of assets and number of employees). In most of the specifications, the effect of one-year returns to shareholders has a positive and statistically significant effect at the $\mathrm{p}<0.1$ level or better. The specification includes controls for S\&P index, and those in the S\&P500 seem to enjoy higher pay, though the effect is not always statistically significant. All specifications include industry fixed effects (2-digit level or 4-digit level). Column 1 also includes 2008 choices. Pay in FY 2008 is not found to be statistically different from 2007. In terms of CEO characteristics, age has a positive and statistically significant effect at conventional levels, whereas CEO tenure (not included here) does not change the results and is not found to have a statistically significant effect.

The main variable of interest in Table 8 is the log of the mean total compensation of all CEOs that the firm chose as its benchmark. The measure, like the other financial measures, is lagged one period as that would be the information available to firms when making the benchmark and

\footnotetext{
${ }^{18}$ As explained above, I exclude a small number of firms that have listed 400 or more firms as their benchmark.
} 
compensation decisions. Column 1 includes a naive specification, where the mean compensation of the benchmark is included directly. The effect is large, and statistically significant at the $\mathrm{p}<0.01$ level. The interpretation of the coefficient suggests that the elasticity of the benchmarks' pay with respect to own pay is 0.39 . If firms were selecting their benchmark purely based on other firm characteristics, such as industry, and size, this result could be interpreted as causal. The rest of the columns use an instrumental variable strategy to account for the possible endogeneity with respect to compensation in choosing one's benchmark.

Columns 2-9 make use of the IV strategy discussed in Section 3.2. In all cases, the instrument for the compensation measure among firm $i$ 's benchmark is the peers-of-peers measure: the average characteristic across firms in the benchmark of firms that are in the benchmark of firm $i$, and themselves are not part of firm $i$ 's benchmark (i.e., firms that belong to the benchmark of the benchmark, and are therefore one-level removed). For example, in column 2, the average (lagged) log sales among the benchmark-of-benchmark firms is used as an IV. Panel B summarizes the results of the first-stage regression. The IV provides a relatively strong first stage. The R-squared of the first stage is 0.74 , and the F-statistic for the excluded instrument is 87.55. Column 3 includes additional instruments of the same type, average log employment and average one-year stock return among the benchmark-of-benchmark firms. The results are virtually the same, though these two additional IVs are weaker compared to the sales IV. Using these multiple sets of IVs, and other similar measures, I am able to perform "over-identification tests.” In all cases, using both GMM and 2SLS I fail to reject the null, and the smallest p-value among all specifications is 0.36 . This provides further support for the use of peers-of-peers as an IV.

To further reduce the threat to the validity of the IV, columns 4-6 further exclude the set of firms used as peers-of-peers. For the IV measure I now include only those that are peers-of-peers and are not in the same 2-digit GICS code (column 4), or not in the same 4-digit SIC code (columns 5-6). The results are very similar in magnitude, though the exclusion of the 2-digit case greatly reduces the sample size, and standard errors for the second stage estimates become very large, as many firms make all of their choices within their own 2-digit sector. Excluding all peers-of-peers at the 4-digit industry level provides a further exclusion and performs well as an IV, as can be seen in Panel B.

Motivated by a growing literature that documents that CEO or firm fixed effects explain a large 
part of the variation in compensation, columns 8 and 9 use a firm fixed effects specification to estimate the effects of others' compensation. ${ }^{19}$ The effect remains large and statistically significant at the $\mathrm{p}<0.05$ level. As expected, the point estimates are larger, suggesting an elasticity of 0.56 and 0.63. With the exception of own-firm sales, the other measures are no longer statistically significant, likely due to the fact that the fixed effects capture much of the variation across two years. Columns 8 and 9 include all firms for which financial information and benchmark choices are available for both fiscal years. To account for turnover among CEOs, I examine only those firms which have had the same CEO throughout FY 2006-2008. Similar results hold if firms that experienced turnover are included. The specifications in columns 8 and 9 have the advantage of controlling for any fixed-over-time unobservables of the firm, the compensation committee, and/or its CEO. Naturally, the first stage instrument is less powerful as the fixed effect accounts for much of the variation.

The most crucial question in any IV setting is whether the instrument is uncorrelated with the unobservable component. In this case two features make this more likely to hold. First, the exclusion restriction assumption here is that the characteristics of a benchmark-of-benchmark firm are uncorrelated with any unobserved factors influencing CEO compensation once controlling for industry, S\&P index, etc. The IV is constructed to include only the characteristics of firms that are one-removed from the examined firm. It is possible that these firms were considered by a firm for inclusion in a benchmark based on their compensation levels, but note that the IV used the non-compensation measures for the instrument. Second, unlike the usual social network or group-formation settings, a benchmark choice by one firm does not require or directly impact the choices made by another, thereby eliminating the simultaneity and feedback effect that are present in other network settings. For example, when considering the choices of firm $i$, if firm $i$ 's peer-ofpeer chooses firm $i$, that firm is excluded from the construction of the instrumental variable group. Last, as can be seen in columns 5-6 of Table 8, the results further hold when only benchmark-ofbenchmark firms not in the same industry are used.

\footnotetext{
${ }^{19}$ Because there are only two years for each firm, this is equivalent to a first-difference estimate.
} 


\subsection{Robustness and alternative specifications}

In this section, I first examine the plausibility of the IV used. The results are summarized in Table 9. The first three columns examine, as before, own compensation as the dependent variable. The first column examines the effect of the IV directly (lagged sales of peers-of-peers), as a reducedform specification is less susceptible to bias. The effect is positive and statistically significant at the $\mathrm{p}<0.01$ level. Though this is not direct evidence of peer effects, the finding that the sales of peer-of-peers matter for own compensation are consistent with a finding of a peer effect. The second column shows the effect of peers-of-peers not in own 4-digit SIC industry. The effect is now smaller, but is still statistically significant at the $\mathrm{p}<0.1$ level.

Column 3 of Table 9 uses the same IV measure (sales of peers-of-peers), but now examines both future (lead) values and lag values. The results for the lead value are smaller in magnitude, and are not statistically significant. Similarly, when only lead values are included, the effect is not statistically significant. This falsification test further substantiates the use of the IV as a valid instrument.

Finally, columns 4-6 examine the effect of the IV chosen, sales of peers-of-peers, on own firm sales, rather than own compensation. The different specifications find that the sales of peers of peers have a small and statistically non-significant effect on own sales. This suggests that the sales of peers-of-peers do not have a directly measurable effect on own sales. In contrast, there is a detectable effect on own firm compensation.

Though using the mean of the benchmark is perhaps a natural choice, firms may choose other deciles as the relevant statistic when setting pay. In fact, in their proxy statements, many firms mention their benchmarking goal is to be competitive with a certain decile, rather than the average. Having several measures for each peer-of-peer choice (such as sales, market value, employment, etc.), I am able to examine several group statistics at the same time, using the same IV strategy detailed above. For example, I compare the effects of the $3^{\text {rd }}, 5^{\text {th }}$, and $7^{\text {th }}$ deciles (all at the same time); or the relative importance of the mean pay of others versus the median pay of others. The results (available upon request), suggest that firms are more affected by higher deciles, such as the 60th or 70th percentile, but not the extreme deciles such as the 80th percentile or higher. Nonetheless, the average pay among other firms is able to capture the effect of other firms' compensation 
on own compensation fairly well.

\section{Conclusion}

I examined the factors that influence a firm's choice of executive compensation benchmark. A recent change in the SEC's filing requirement allowed me to compile a new dataset that details every firm's actual choice of comparison group. The results show that after controlling for firm characteristics such as own size and own executive compensation, firms are more likely to choose larger firms, and firms that highly compensate their CEOs. Using the time panel-data nature of the sample, I find that the preference for higher-compensation peers is limited to firms within one's own sector.

The findings are consistent with the anecdotal evidence that executives seek to be paid at least as much as their peers, thus explaining some of the upward spiral in executive compensation during the last few decades. However, it is possible that firms are attracted to other successful firms for other reasons, and that those firms also happen to provide their executives with higher compensation. A better understanding of the process governing firms' benchmarking practices can help firms to better understand how their compensation practices affect other firms, and in turn, their entire industry.

I make use of the complete mapping of choices among the S\&P 900 firms and use peers-ofpeers as an instrumental variable strategy to examine the causal effect of others' pay on own pay. I find that the elasticity of own pay with respect to others' pay is positive and statistically significant. This effect implies the existence of a social multiplier in compensation. Over time, as firms react to pay increases among their benchmark they, in turn, cause other firms to raise their pay, as each firm might be part of another firm's benchmark. This effect is consistent with the (real) increase in total compensation over the last few decades.

From a regulation perspective, though the SEC could enhance and expand the guidelines regarding the choice of benchmark, such regulation is not likely to have a large effect on CEO compensation. This is due to the fact that currently there are no guidelines as to how to use benchmarks for setting pay. Similarly, if firms were forced to set pay according to their benchmark (for example, taxing firms that pay more than the median), then the incentives to strategically choose 
the benchmark would greatly increase.

Currently, this paper focuses on the compensation of CEOs. However, it would be of interest to examine whether the patterns uncovered here are similar for other executives, as data for the top five executives is readily available. Further work might examine whether and how executive compensation is determined, once a firm decides on its benchmarks. This could uncover how the compensation of peer CEOs affects one's own compensation, and uncover the underlying mechanisms. For instance, are CEOs affected by others due to the use of relative performance evaluation measures, or are CEOs exerting influence on the compensation committee to increase their pay and keep up with their peers? Uncovering the relative importance of these mechanisms can be useful in any future debate on the normative issues surrounding executive compensation.

\section{References}

Angrist, Joshua and Jorn-Steffen Pischke, Mostly Harmless Econometrics: An Empiricist's Companion, Princeton University Press, 2008.

Antle, Rick and Abbie Smith, "An Empirical Investigation of the Relative Performance Evaluation of Corporate Executives," Journal of Accounting Research, 1986, 24, 1-39.

Babcock, Linda, Xianghong Wang, and George Loewenstein, "Choosing the Wrong Pond: Social Comparisons in Negotiations that Reflect a Self-Serving Bias," The Quarterly Journal of Economics, 1996, 111 (1), 1-19.

Bannister, James W. and Harry A. Newman, "Analysis of Corporate Disclosures on Relative Performance Evaluation," Accounting Horizons, 2003, 17, 235-246.

Bayer, Patrick, Randi Hjalmarsson, and David E. Pozen, "Building Criminal Capital Behind Bars: Peer Effects in Juvenile Corrections," The Quarterly Journal of Economics, 2009, $124,105-147$.

Bebchuk, Lucian and Yaniv Grinstein, "The Growth of Executive Pay," Oxford Review of Economic Policy, 2005, 21, 283-303.

Bertrand, Marianne, “CEOs," Annual Review of Economics, 2009, 1(1), 121-50.

, Erzo Luttmer, and Sendhil Mullainathan, "Network effects and welfare cultures," The Quarterly Journal of Economics, 2000, 115 (3), 1019.

Dash, Eric, "Executive Pay: A Special Report," The New York Times, April 82007.

De Giorgi, Giacomo, Michele Pellizzari, and Silvia Redaelli, "Identification of Social Interactions Through Partially Overlapping Peer Groups," American Economic Journal: Applied Economics, 2010, 2, 241-75.

Faulkender, Michael and Jun Yang, "Inside the Black Box: The Role and Composition of Compensation Peer Groups,' Journal of Financial Economics, 2010, 96, 257-270. 
Festinger, Leon, “A theory of social comparison processes," Human Relations, 1954, 7, 117-140.

Finkelstein, Sydney, Donald C. Hambrick, and Albert A. Cannella, Strategic leadership: Theory and research on executives, top management teams, and boards, Oxford University Press, 2009.

Gibbons, Robert and Kevin J. Murphy, "Relative Performance Evaluation for Chief Executive Officers," Industrial and Labor Relations Review, 1990, 43, 30S-51S.

Hayes, Rachel M and Scott Schaefer, "CEO Pay and the Lake Wobegon Effect," working paper, 2007.

Jackson, Matthew O., "A Survey of Models of Network Formation: Stability and Efficiency," in Gabrielle Demange and Myrna Wooders, eds., Group Formation in Economics; Networks, Clubs and Coalitions, Cambridge U.K.: Cambridge University Press, 2004, chapter 1.

Laschever, Ron, “The Doughboys Network: Social Interactions and Labor Market Outcomes of World War I Veterans," Mimeo, 2009, University of Illinois at Urbana-Champaign.

McFadden, Daniel, "Conditional Logit Analysis of Qualitative Choice Behavior," in P. Zarembka, ed., Frontiers in Econometrics, Academic Press New York 1974, pp. 105-142.

Morgenson, Gretchen, “Peer Pressure: Inflating Executive Pay," The New York Times, November 262006.

Murphy, Kevin J., "Executive Compensation," in Orley Ashenfelter and David Card, eds., Handbook of Labor Economics, , Vol. 3b Elsevier Science North Holland 1999, pp. 2485-2563.

O'Reilly, Charles A., Brian G. Main, and Graef S. Crystal, "CEO Compensation as Tournament and Social Comparison: A Tale of Two Theories," Administrative Science Quarterly, 1988, 33, 257-274.

Piketty, Thomas and Emmanuel Saez, "Income Inequality in the United States, 1913-1998," Quarterly Journal of Economics, 2003, 118, 1-39.

Porac, Joseph F., James B. Wade, and Timothy G. Pollock, "Industry Categories and the Politics of the Comparable Firm in CEO Compensation," Administrative Science Quarterly, 1999, $44,112-144$.

Securities and Exchange Commission, Executive Compensation and Related Person Disclosure Release 33-8732A 2006. 
Table 1: Summary Statistics for FY2006 Financials and FY2007-FY2008 Benchmarking Lists

\begin{tabular}{|c|c|c|c|c|c|c|c|c|c|}
\hline \multirow[b]{2}{*}{ Variable } & \multicolumn{3}{|c|}{ Firms in S\&P 500* } & \multicolumn{3}{|c|}{ Firms in S\&P MidCap* } & \multicolumn{3}{|c|}{$\begin{array}{c}\text { Firms in the Compustat } \\
\text { database } \\
(\mathrm{n}=1,753)\end{array}$} \\
\hline & $\begin{array}{l}\text { Mean } \\
\text { (s.d.) }\end{array}$ & Min & Max & $\begin{array}{l}\text { Mean } \\
\text { (s.d.) }\end{array}$ & Min & Max & $\begin{array}{l}\text { Mean } \\
\text { (s.d.) }\end{array}$ & Min & Max \\
\hline \multicolumn{10}{|c|}{$\begin{array}{l}\text { Number of peers } \\
\text { listed in benchmark** }\end{array}$} \\
\hline Fiscal Year 2007: & $\begin{array}{l}21.81 \\
(17.13)\end{array}$ & 4 & 179 & $\begin{array}{l}21.05 \\
(19.77)\end{array}$ & 3 & 195 & & & \\
\hline Fiscal Year 2008: & $\begin{array}{l}21.44 \\
(17.09)\end{array}$ & 3 & 150 & $\begin{array}{l}20.22 \\
(16.69)\end{array}$ & 3 & 153 & & & \\
\hline $\begin{array}{l}\text { FY06 Salary } \\
\text { (thousands of \$) }\end{array}$ & $\begin{array}{l}1,011.22 \\
(477.89)\end{array}$ & 0 & 5,613 & $\begin{array}{l}712.96 \\
(245.88)\end{array}$ & 0 & 1,600 & $\begin{array}{l}738.78 \\
(385.37)\end{array}$ & 0 & 5,613 \\
\hline $\begin{array}{l}\text { FY06 Bonus } \\
\text { (thousands of \$) }\end{array}$ & $\begin{array}{l}855.86 \\
(2,881.05)\end{array}$ & 0 & 31,000 & $\begin{array}{l}364.95 \\
(1,181.84)\end{array}$ & 0 & 17,531 & $\begin{array}{l}452.20 \\
(1738.89)\end{array}$ & 0 & 31,000 \\
\hline $\begin{array}{l}\text { FY06 Total } \\
\text { Compensation } \\
\text { (thousands of \$) }\end{array}$ & $\begin{array}{l}10,524.45 \\
(10,928.65)\end{array}$ & 0.001 & 131,249 & $\begin{array}{l}4,257.47 \\
(4,141.71)\end{array}$ & 3.48 & 31,872 & $\begin{array}{l}5,280.20 \\
(7,477.47)\end{array}$ & 0.001 & 131,249 \\
\hline $\begin{array}{l}\text { FY06 Market Val. } \\
\text { (millions of \$) }\end{array}$ & $\begin{array}{l}24,885.62 \\
(43,676.89)\end{array}$ & 1,414 & 446,943 & $\begin{array}{l}2,714.72 \\
(1,306.37)\end{array}$ & 687.10 & 10,019 & $\begin{array}{l}8,495.57 \\
(25,417.5)\end{array}$ & 0.09 & 446,943 \\
\hline $\begin{array}{l}\text { FY06 Sales } \\
\text { (millions of \$) }\end{array}$ & $\begin{array}{l}16,613.2 \\
(32,025.21)\end{array}$ & 322.82 & 345,977 & $\begin{array}{l}2,376.13 \\
(2,945.38)\end{array}$ & 159.63 & 31,357 & $\begin{array}{l}6,068.23 \\
(18,882.0)\end{array}$ & 0 & 345,977 \\
\hline $\begin{array}{l}\text { FY06 Number of } \\
\text { employees (in } \\
\text { thousands) }\end{array}$ & $\begin{array}{l}45.90 \\
(107.57)\end{array}$ & 0.113 & 1,900 & $\begin{array}{l}11.13 \\
(41.53)\end{array}$ & 0.001 & 759 & $\begin{array}{l}19.02 \\
(63.35)\end{array}$ & 0 & 1,900 \\
\hline In S\&P 500 index & & & & & & & $27.32 \%$ & & \\
\hline In MidCap index & & & & & & & $20.19 \%$ & & \\
\hline In SmallCap index & & & & & & & $28.46 \%$ & & \\
\hline
\end{tabular}

Notes:

* Includes only all those for which all 2006 financial data are available.

** Choices derived from Fiscal Year 2007 and 2008. Excluding firms choosing more than 400 firms.

Standard deviations in parentheses. 
Table 2: Joint Distribution of Choosing and Chosen Firms (S\&P 500 firms only, Fiscal Year 2007)

\section{Panel A: CEO Total Compensation}

\begin{tabular}{|c|c|c|c|c|}
\hline Choser & Bottom quartile & $2^{\text {nd }}$ quartile & $3^{\text {rd }}$ quartile & Top quartile \\
\hline Bottom quartile & 536 & 565 & 512 & 332 \\
\hline $2^{\text {nd }}$ quartile & 435 & 569 & 574 & 410 \\
\hline $3^{\text {rd }}$ quartile & 240 & 388 & 577 & 657 \\
\hline Top quartile & 197 & 270 & 514 & 1,165 \\
\hline
\end{tabular}

Panel B: Industry

\begin{tabular}{lrrrrr}
\hline \multicolumn{1}{c}{ Chosen } & \multicolumn{1}{c}{$\begin{array}{l}\text { Mining \& } \\
\text { Manufacturing }\end{array}$} & Financial Services & Utilities & \multicolumn{2}{c}{ Other Industries } \\
\cline { 3 - 6 } Choosing & 1,371 & 51 & 52 & 591 \\
Mining \& Manufacturing & 72 & 880 & 17 & 150 \\
Financial Services & 96 & 20 & 595 & 55 \\
Utilities & 755 & 145 & 40 & 3,108 \\
\hline
\end{tabular}

Notes: Each cell summarizes the number of times each choosing-chosen pair (both from the S\&P 500) is observed in a benchmark list of an S\&P 500 firm. 
Table 3: Determinants of Firms Being Included in the Benchmark Lists of S\&P 500 Firms

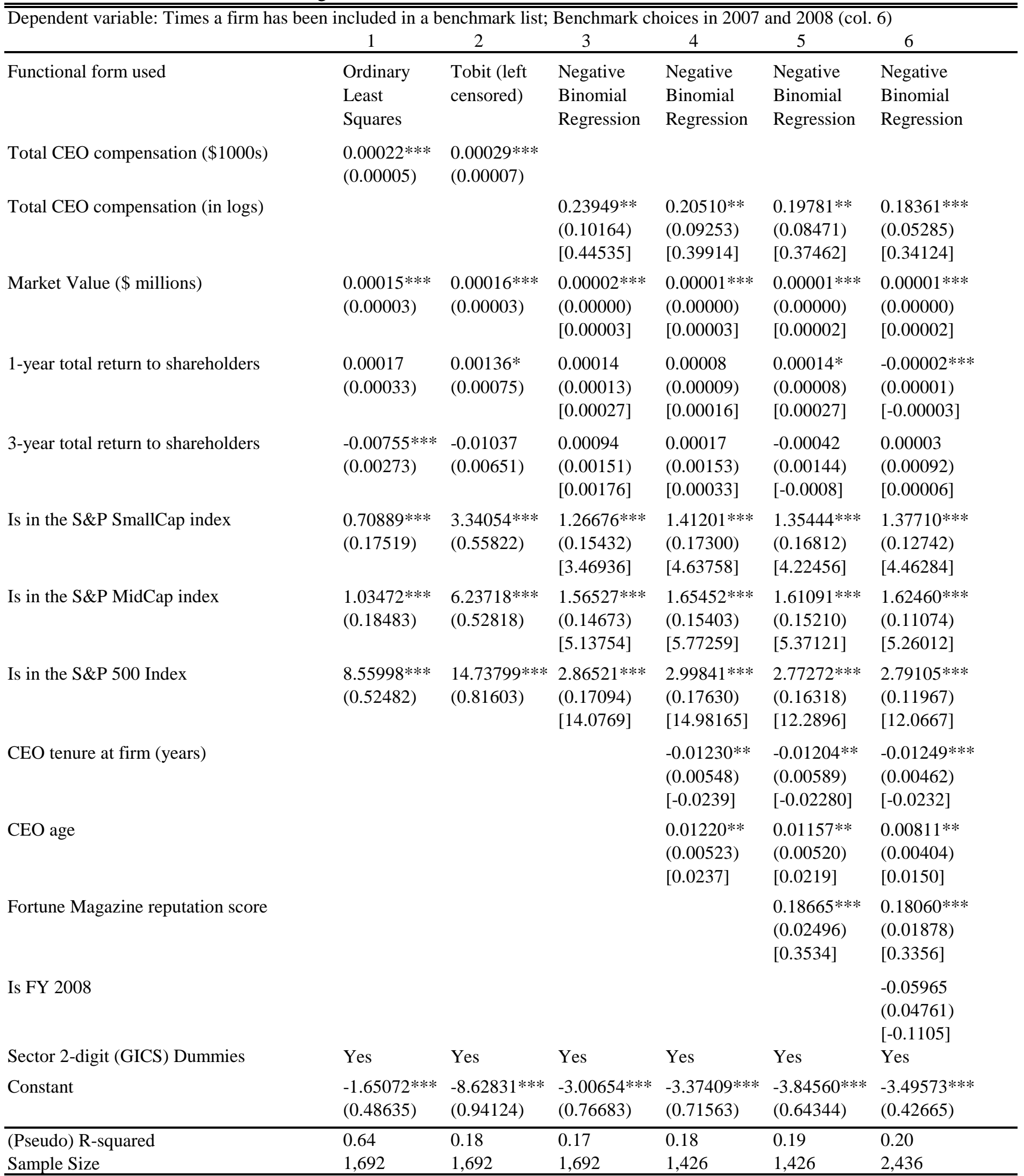

Notes: * significant at $10 \%$; ** significant at $5 \%$; *** significant at $1 \%$

Robust standard errors in parentheses.

Marginal effects, evaluated at the mean, are in squared brackets.

All financial measures are lagged one year. All specifications include controls for total sales, assets, and number of employees.

The choosing firms sample is only S\&P 500 firms. The available choices are all 1,692 firms with available information in FY 2007. 
Table 4: Determinants of Firms Being Included in the Benchmark Lists of MidCap Firms

\begin{tabular}{|c|c|c|c|c|c|c|}
\hline & 1 & 2 & 3 & 4 & 5 & 6 \\
\hline Functional form used & $\begin{array}{l}\text { Ordinary } \\
\text { Least } \\
\text { Squares }\end{array}$ & $\begin{array}{l}\text { Tobit (left } \\
\text { censored) }\end{array}$ & $\begin{array}{l}\text { Negative } \\
\text { Binomial } \\
\text { Regression }\end{array}$ & $\begin{array}{l}\text { Negative } \\
\text { Binomial } \\
\text { Regression }\end{array}$ & $\begin{array}{l}\text { Negative } \\
\text { Binomial } \\
\text { Regression }\end{array}$ & $\begin{array}{l}\text { Negative } \\
\text { Binomial } \\
\text { Regression }\end{array}$ \\
\hline Total CEO compensation ( $\$ 1000$ s) & $\begin{array}{l}0.0000^{* *} \\
(0.0000)\end{array}$ & $\begin{array}{l}0.0001^{* * *} \\
(0.0000)\end{array}$ & & & & \\
\hline Total CEO compensation (in logs) & & & $\begin{array}{l}0.3257 * * * \\
(0.0312) \\
{[0.6770]}\end{array}$ & $\begin{array}{l}0.3095^{* * *} \\
(0.0337) \\
{[0.6690]}\end{array}$ & $\begin{array}{l}0.3174 * * * \\
(0.0336) \\
{[0.6865]}\end{array}$ & $\begin{array}{l}0.3268^{* * *} \\
(0.0359) \\
{[0.7294]}\end{array}$ \\
\hline Market Value ( $\$$ billions) & $\begin{array}{l}-0.0070^{*} \\
(0.0040)\end{array}$ & $\begin{array}{l}-0.0142 * * \\
(0.0057)\end{array}$ & $\begin{array}{l}-0.0041 * \\
(0.0022) \\
{[0.0085]}\end{array}$ & $\begin{array}{l}-0.0043 * \\
(0.0023) \\
{[-0.0094]}\end{array}$ & $\begin{array}{l}-0.0038 * \\
(0.0022) \\
{[0.0083]}\end{array}$ & $\begin{array}{l}-0.0057 * * * \\
(0.0016) \\
{[-0.012]}\end{array}$ \\
\hline 1-year total return to shareholders & $\begin{array}{l}-0.0005^{* * *} \\
(0.0002)\end{array}$ & $\begin{array}{l}-0.0018 * \\
(0.0010)\end{array}$ & $\begin{array}{l}-0.0006 \\
(0.0004) \\
{[-0.0012]}\end{array}$ & $\begin{array}{l}-0.0004 \\
(0.0003) \\
{[-0.0008]}\end{array}$ & $\begin{array}{l}-0.0004 \\
(0.0003) \\
{[-0.0009]}\end{array}$ & $\begin{array}{l}-0.0006 \\
(0.0005) \\
{[-0.0013]}\end{array}$ \\
\hline 3-year total return to shareholders & $\begin{array}{l}-0.0012 \\
(0.0015)\end{array}$ & $\begin{array}{l}0.0000 \\
(0.0024)\end{array}$ & $\begin{array}{l}-0.0011 \\
(0.0009) \\
{[-0.0022]}\end{array}$ & $\begin{array}{l}-0.0012 \\
(0.0010) \\
{[-0.0025]}\end{array}$ & $\begin{array}{l}-0.0012 \\
(0.0009) \\
{[-0.0025]}\end{array}$ & $\begin{array}{l}-0.0016^{*} \\
(0.0009) \\
{[-0.0036]}\end{array}$ \\
\hline Is in the S\&P SmallCap index & $\begin{array}{l}0.1744 \\
(0.1322)\end{array}$ & $\begin{array}{l}0.0742 \\
(0.2329)\end{array}$ & $\begin{array}{l}0.0129 \\
(0.0875) \\
{[0.0269]}\end{array}$ & $\begin{array}{l}-0.0292 \\
(0.1054) \\
{[-0.0625]}\end{array}$ & $\begin{array}{l}-0.0297 \\
(0.1051) \\
{[-0.0637]}\end{array}$ & $\begin{array}{l}-0.0459 \\
(0.0845) \\
{[-0.1008]}\end{array}$ \\
\hline Is in the S\&P MidCap index & $\begin{array}{l}2.6226^{* * *} \\
(0.1914)\end{array}$ & $\begin{array}{l}3.5536^{* * *} \\
(0.2438)\end{array}$ & $\begin{array}{l}0.9234 * * * \\
(0.0734) \\
{[2.6210]}\end{array}$ & $\begin{array}{l}0.8820 \text { *** } \\
(0.0767) \\
{[2.5324]}\end{array}$ & $\begin{array}{l}0.8863 * * * \\
(0.0768) \\
{[2.5502]}\end{array}$ & $\begin{array}{l}0.9074 * * * \\
(0.0580) \\
{[2.6903]}\end{array}$ \\
\hline Is in the S\&P 500 Index & $\begin{array}{l}2.7012^{* * *} \\
(0.1905)\end{array}$ & $\begin{array}{l}3.7543^{* * *} \\
(0.2462)\end{array}$ & $\begin{array}{l}0.8781 \text { *** } \\
(0.0796) \\
{[2.3001]}\end{array}$ & $\begin{array}{l}0.8877 * * * \\
(0.0842) \\
{[2.3628]}\end{array}$ & $\begin{array}{l}0.9246 * * * \\
(0.0852) \\
{[2.4873]}\end{array}$ & $\begin{array}{l}0.9443 * * * \\
(0.0690) \\
{[2.6234]}\end{array}$ \\
\hline CEO tenure at firm (years) & & & & $\begin{array}{l}-0.0022 \\
(0.0043) \\
{[-0.0047]}\end{array}$ & $\begin{array}{l}-0.0023 \\
(0.0043) \\
{[-0.0050]}\end{array}$ & $\begin{array}{l}-0.0009 \\
(0.0032) \\
{[-0.0021]}\end{array}$ \\
\hline CEO age & & & & $\begin{array}{l}-0.0053 \\
(0.0041) \\
{[-0.0114]}\end{array}$ & $\begin{array}{l}-0.0054 \\
(0.0041) \\
{[-0.0116]}\end{array}$ & $\begin{array}{l}-0.0074 * * \\
(0.0032) \\
{[-0.0165]}\end{array}$ \\
\hline Fortune Magazine reputation score & & & & & $\begin{array}{l}-0.0416 * * \\
(0.0187) \\
{[-0.0900]}\end{array}$ & $\begin{array}{l}-0.0301^{* *} \\
(0.0143) \\
{[-0.0671]}\end{array}$ \\
\hline Is FY 2008 & & & & & & $\begin{array}{l}0.0075 \\
(0.0379) \\
{[0.0166]}\end{array}$ \\
\hline \multicolumn{7}{|l|}{ Sector 2-digit (GICS) Dummies } \\
\hline Constant & $\begin{array}{l}-1.65072^{* * *} \\
(0.48635)\end{array}$ & $\begin{array}{l}-8.62831^{* * *} \\
(0.94124)\end{array}$ & $\begin{array}{l}-3.00654 * * * \\
(0.76683)\end{array}$ & $\begin{array}{l}-3.37409 * * * \\
(0.71563)\end{array}$ & $\begin{array}{l}-3.84560^{* * *} \\
(0.64344)\end{array}$ & $\begin{array}{l}-3.49573^{* * *} \\
(0.42665)\end{array}$ \\
\hline (Pseudo) R-squared & 0.28 & 0.08 & 0.09 & 0.09 & 0.09 & 0.10 \\
\hline Sample Size & 1,692 & 1,692 & 1,692 & 1,426 & 1,426 & 2,436 \\
\hline
\end{tabular}

Notes: * significant at $10 \%$; ** significant at $5 \%$; ** significant at $1 \%$

Robust standard errors in parentheses.

Marginal effects, evaluated at the mean, are in squared brackets.

All financial measures are lagged one year. All specifications include controls for total sales, assets, and number of employees.

The choosing firms sample is only S\&P MidCap firms. The available choices are all 1,692 firms available in FY 2007. 
Table 5: OLS Estimates of Benchmark Choices Including Choosing-Firm Characteristics

\begin{tabular}{|c|c|c|c|c|c|c|}
\hline \multicolumn{7}{|c|}{ Binary dependent variable: Is firm $j$ chosen by firm $i$; Fiscal Year 2007} \\
\hline & 1 & 2 & 3 & 4 & 5 & 6 \\
\hline \multicolumn{7}{|l|}{ Firm j (candidate) characteristics } \\
\hline Total CEO compensation (in logs) & $\begin{array}{l}0.0008^{* * *} \\
(0.0001)\end{array}$ & $\begin{array}{l}0.0009 * * * \\
(0.0001)\end{array}$ & $\begin{array}{l}0.0009 * * * \\
(0.0001)\end{array}$ & $\begin{array}{l}0.0008^{* * *} \\
(0.0001)\end{array}$ & $\begin{array}{l}0.0007 * * * \\
(0.0001)\end{array}$ & $\begin{array}{l}-0.0005^{* * *} \\
(0.0002)\end{array}$ \\
\hline \multicolumn{4}{|c|}{ Difference in total CEO compensation (in logs) } & $\begin{array}{l}0.0001 \\
(0.0001)\end{array}$ & $\begin{array}{l}-0.0004^{* *} \\
(0.0002)\end{array}$ & $\begin{array}{l}-0.0010^{* * *} \\
(0.0002)\end{array}$ \\
\hline \multicolumn{6}{|c|}{$\begin{array}{l}\text { Benchmark firm is higher compensation X } \\
\text { Difference in total CEO compensation (in logs) }\end{array}$} & $\begin{array}{l}0.0007 * * * \\
(0.0001)\end{array}$ \\
\hline Total sales (in logs) & $\begin{array}{l}-0.0002 \\
(0.0003)\end{array}$ & $\begin{array}{l}-0.0002 \\
(0.0003)\end{array}$ & $\begin{array}{l}-0.0002 \\
(0.0003)\end{array}$ & $\begin{array}{l}0.0000 \\
(0.0003)\end{array}$ & $\begin{array}{l}0.0002 \\
(0.0003)\end{array}$ & $\begin{array}{l}0.0001 \\
(0.0003)\end{array}$ \\
\hline Number of employees (in logs) & $\begin{array}{l}0.0006^{* * *} \\
(0.0002)\end{array}$ & $\begin{array}{l}0.0006^{* * *} \\
(0.0002)\end{array}$ & $\begin{array}{l}0.0006^{* * *} \\
(0.0002)\end{array}$ & $\begin{array}{l}0.0006 * * * \\
(0.0002)\end{array}$ & $\begin{array}{l}0.0009 * * * \\
(0.0002)\end{array}$ & $\begin{array}{l}0.0010^{* * *} \\
(0.0002)\end{array}$ \\
\hline Assets (in logs) & $\begin{array}{l}0.0001 \\
(0.0003)\end{array}$ & $\begin{array}{l}0.0001 \\
(0.0003)\end{array}$ & $\begin{array}{l}0.0001 \\
(0.0003)\end{array}$ & $\begin{array}{l}0.0006 * * \\
(0.0002)\end{array}$ & $\begin{array}{l}0.0019 * * * \\
(0.0003)\end{array}$ & $\begin{array}{l}0.0018^{* * *} \\
(0.0003)\end{array}$ \\
\hline Market value (in logs) & $\begin{array}{l}0.0029 * * * \\
(0.0003)\end{array}$ & $\begin{array}{l}0.0029 * * * \\
(0.0003)\end{array}$ & $\begin{array}{l}0.0029 * * * \\
(0.0003)\end{array}$ & $\begin{array}{l}0.0028 * * * \\
(0.0003)\end{array}$ & $\begin{array}{l}0.0033^{* * * *} \\
(0.0003)\end{array}$ & $\begin{array}{l}0.0033^{* * *} \\
(0.0003)\end{array}$ \\
\hline 1-year total return to shareholders & $\begin{array}{l}-0.0000 * \\
(0.0000)\end{array}$ & $\begin{array}{l}-0.0000 * \\
(0.0000)\end{array}$ & $\begin{array}{l}-0.0000 * \\
(0.0000)\end{array}$ & $\begin{array}{l}0.0000 \\
(0.0000)\end{array}$ & $\begin{array}{l}0.0000^{*} \\
(0.0000)\end{array}$ & $\begin{array}{l}0.0000 \\
(0.0000)\end{array}$ \\
\hline 3-year total return to shareholders & $\begin{array}{l}-0.0000^{* * *} \\
(0.000)\end{array}$ & $\begin{array}{l}-0.0000^{* * * *} \\
(0.0000)\end{array}$ & $\begin{array}{l}-0.0000 * * * \\
(0.0000)\end{array}$ & $\begin{array}{l}-0.0000 * * * \\
(0.0000)\end{array}$ & $\begin{array}{l}-0.0000 * * * \\
(0.0000)\end{array}$ & $\begin{array}{l}-0.0000^{* * * *} \\
(0.0000)\end{array}$ \\
\hline \multicolumn{7}{|l|}{ Difference between firm i and $j$} \\
\hline \multicolumn{4}{|l|}{ Difference in total sales (in logs) } & $\begin{array}{l}-0.0015 * * * \\
(0.0002)\end{array}$ & $\begin{array}{l}-0.0036 * * * \\
(0.0003)\end{array}$ & $\begin{array}{l}-0.0036^{* * *} \\
(0.0003)\end{array}$ \\
\hline \multicolumn{4}{|c|}{ Difference in number of employees (in logs) } & $\begin{array}{l}-0.0007^{* * * *} \\
(0.0001)\end{array}$ & $\begin{array}{l}-0.0023 * * * \\
(0.0002)\end{array}$ & $\begin{array}{l}-0.0023 * * * \\
(0.0002)\end{array}$ \\
\hline \multicolumn{4}{|l|}{ Difference in assets (in logs) } & $\begin{array}{l}-0.0009 * * * \\
(0.0001)\end{array}$ & $\begin{array}{l}-0.0025^{* * *} \\
(0.0002)\end{array}$ & $\begin{array}{l}-0.0026^{* * * *} \\
(0.0002)\end{array}$ \\
\hline \multicolumn{4}{|l|}{ Difference in market value (in logs) } & $\begin{array}{l}0.0010^{* * * *} \\
(0.0002)\end{array}$ & $\begin{array}{l}-0.0011^{* * * *} \\
(0.0002)\end{array}$ & $\begin{array}{l}-0.0011 * * * \\
(0.0002)\end{array}$ \\
\hline \multicolumn{4}{|l|}{ In same S\&P Index } & $\begin{array}{l}0.0106^{* * *} \\
(0.0008)\end{array}$ & $\begin{array}{l}0.0060^{* * *} \\
(0.0005)\end{array}$ & $\begin{array}{l}0.0059 * * * \\
(0.0005)\end{array}$ \\
\hline \multicolumn{4}{|l|}{ In same industry } & $\begin{array}{l}0.0408^{* * *} \\
(0.0013)\end{array}$ & $\begin{array}{l}0.0416^{* * *} \\
(0.0014)\end{array}$ & $\begin{array}{l}0.0416^{* * *} \\
(0.0014)\end{array}$ \\
\hline Includes consulting firms dummies & No & No & Yes & No & No & No \\
\hline Includes choosing-firm characteristics & No & Yes & Yes & No & No & No \\
\hline Choosing-firm fixed effects & No & No & No & No & Yes & Yes \\
\hline S\&P Index and Industry fixed effects & Yes & Yes & Yes & Yes & Yes & Yes \\
\hline R-squared & 0.008 & 0.009 & 0.009 & 0.035 & 0.043 & 0.043 \\
\hline Sample Size & $1,391,044$ & $1,389,332$ & $1,389,332$ & $1,390,229$ & $1,390,229$ & $1,390,229$ \\
\hline
\end{tabular}

Notes: * significant at $10 \%$; ** significant at $5 \%$; ${ }^{* * *}$ significant at $1 \%$. Standard errors, in parentheses, are clustered at the choosing-firm level. Each observation represents one possible choosing firm and benchmark firm choice combination. All financial measures are lagged one year. All difference measures are measured in natural logs of the absolute value of the difference between the choosing and potential benchmark firm choice. Choosing firm characteristics include logs of sales, number of employees, market value, total compensation, and 1- and 3-year stock returns. 
Table 6: OLS Estimates of Benchmark Choices with Choosing X Chosen Fixed Effects

\begin{tabular}{|c|c|c|c|c|c|c|}
\hline \multicolumn{7}{|c|}{ 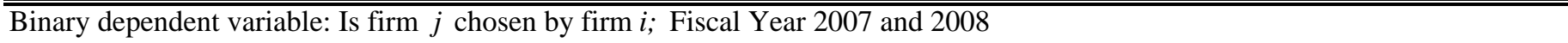 } \\
\hline & 1 & 2 & 3 & 4 & 5 & 6 \\
\hline \multicolumn{7}{|l|}{ Firm $j$ (candidate) characteristics } \\
\hline Total CEO compensation (in logs) & $\begin{array}{l}0.0006^{* * *} \\
(0.0001)\end{array}$ & $\begin{array}{l}0.0006^{* * *} \\
(0.0001)\end{array}$ & $\begin{array}{l}0.0007 * * * \\
(0.0002)\end{array}$ & $\begin{array}{l}0.0003 \\
(0.0002)\end{array}$ & $\begin{array}{l}-0.0002 \\
(0.0002)\end{array}$ & $\begin{array}{l}-0.0001 \\
(0.0001)\end{array}$ \\
\hline $\begin{array}{l}\text { Difference in total CEO compensation (in logs) } \mathrm{X} \\
\text { choosing and candidate are in the same sector }\end{array}$ & & & & & $\begin{array}{l}0.0038 * * * \\
(0.0009)\end{array}$ & $\begin{array}{l}0.0014^{* *} \\
(0.0006)\end{array}$ \\
\hline Is Fiscal Year 2008 & $\begin{array}{l}-0.0001 \\
(0.0001)\end{array}$ & $\begin{array}{l}0.0001 \\
(0.0003)\end{array}$ & $\begin{array}{l}0.0001 \\
(0.0003)\end{array}$ & & & $\begin{array}{l}0.0004 \\
(0.0003)\end{array}$ \\
\hline Total sales (in logs) & $\begin{array}{l}-0.0003^{* * *} \\
(0.0001)\end{array}$ & $\begin{array}{l}-0.0001 \\
(0.0003)\end{array}$ & $\begin{array}{l}-0.0004 \\
(0.0003)\end{array}$ & $\begin{array}{l}-0.0005 \\
(0.0003)\end{array}$ & $\begin{array}{l}-0.0005^{*} \\
(0.0003)\end{array}$ & $\begin{array}{l}-0.0005^{* *} \\
(0.0002)\end{array}$ \\
\hline Number of employees (in logs) & $\begin{array}{l}0.0007^{* * *} \\
(0.0001)\end{array}$ & $\begin{array}{l}0.0006 * * * \\
(0.0002)\end{array}$ & $\begin{array}{l}0.0008^{* * *} \\
(0.0002)\end{array}$ & $\begin{array}{l}0.0003 \\
(0.0005)\end{array}$ & $\begin{array}{l}0.0003 \\
(0.0005)\end{array}$ & $\begin{array}{l}0.0006^{*} \\
(0.0004)\end{array}$ \\
\hline Assets (in logs) & $\begin{array}{l}0.0002^{* *} \\
(0.0001)\end{array}$ & $\begin{array}{l}0.0001 \\
(0.0002)\end{array}$ & $\begin{array}{l}0.0002 \\
(0.0002)\end{array}$ & $\begin{array}{l}0.0007 \\
(0.0006)\end{array}$ & $\begin{array}{l}0.0007 \\
(0.0006)\end{array}$ & $\begin{array}{l}0.0001 \\
(0.0003)\end{array}$ \\
\hline Market value (in logs) & $\begin{array}{l}0.0028^{* * *} \\
(0.0001)\end{array}$ & $\begin{array}{l}0.0030^{* * *} \\
(0.0003)\end{array}$ & $\begin{array}{l}0.0033^{* * *} \\
(0.0003)\end{array}$ & $\begin{array}{l}0.0009 * * * \\
(0.0003)\end{array}$ & $\begin{array}{l}0.0009 * * * \\
(0.0003)\end{array}$ & $\begin{array}{l}0.0008^{* * *} \\
(0.0002)\end{array}$ \\
\hline 1-year total return to shareholders & $\begin{array}{l}-0.0000^{* * *} \\
(0.0000)\end{array}$ & $\begin{array}{l}-0.0000^{* * *} \\
(0.0000)\end{array}$ & $\begin{array}{l}-0.0000 * * * \\
(0.0000)\end{array}$ & $\begin{array}{l}0.0000 \\
(0.0000)\end{array}$ & $\begin{array}{l}0.0000 \\
(0.0000)\end{array}$ & $\begin{array}{l}0.0000 \\
(0.0000)\end{array}$ \\
\hline 3-year total return to shareholders & $\begin{array}{l}-0.0000^{* * *} \\
(0.0000)\end{array}$ & $\begin{array}{l}-0.0000^{* * *} \\
(0.0000)\end{array}$ & $\begin{array}{l}-0.0000^{* * *} \\
(0.0000)\end{array}$ & $\begin{array}{l}0.0000 \\
(0.0000)\end{array}$ & $\begin{array}{l}0.0000 \\
(0.0000)\end{array}$ & $\begin{array}{l}0.0000 \\
(0.0000)\end{array}$ \\
\hline In S\&P SmallCap & $\begin{array}{l}-0.0007 * * * \\
(0.0002)\end{array}$ & $\begin{array}{l}-0.0006 * * * \\
(0.0002)\end{array}$ & $\begin{array}{l}-0.0007^{* * *} \\
(0.0002)\end{array}$ & & & \\
\hline In S\&P MidCap & $\begin{array}{l}-0.0006^{* * *} \\
(0.0002)\end{array}$ & $\begin{array}{l}-0.0003 \\
(0.0004)\end{array}$ & $\begin{array}{l}-0.0006 \\
(0.0005)\end{array}$ & & & \\
\hline In S\&P 500 & $\begin{array}{l}0.0058^{* * *} \\
(0.0002)\end{array}$ & $\begin{array}{l}0.0059 * * * \\
(0.0005)\end{array}$ & $\begin{array}{l}0.0050^{* * *} \\
(0.0006)\end{array}$ & & & \\
\hline Includes choosing-firm characteristics & No & Yes & Yes & Yes & Yes & Yes \\
\hline Choosing-firm fixed effects & Yes & Yes & Yes & Yes & Yes & Yes \\
\hline Choosing X chosen and chosen fixed effects & No & No & No & Yes & Yes & Yes \\
\hline Excludes firms that experienced CEO turnover & No & No & Yes & Yes & Yes & No \\
\hline GICS industry fixed effects & Yes & Yes & Yes & & & \\
\hline R-squared & 0.007 & 0.008 & 0.008 & 0.006 & 0.034 & 0.032 \\
\hline Sample Size & $2,864,970$ & $2,593,831$ & $2,085,458$ & $2,085,458$ & $2,085,458$ & $2,593,831$ \\
\hline
\end{tabular}

Notes: * significant at $10 \%$; ${ }^{* *}$ significant at $5 \%$; ** significant at $1 \%$

Standard errors, in parentheses, are clustered at the choosing-firm level in columns 2-6. Each observation represents one possible choosing firm and benchmark firm choice combination. All financial measures are lagged one year. Choosing firm characteristics include logs of sales, number of employees, market value, total compensation, and 1- and 3-year stock returns. 
Table 7: Estimates of Benchmark Choices with CEO Characteristics and Board of Directors Interactions

Binary dependent variable: Is firm $j$ chosen by firm $i$; Fiscal Year 2007; Choosing-firm fixed effects in columns 2-8; OLS

\section{CEO of choosing firm $i$ is also board chairperson $\mathrm{X}$ total CEO}

compensation (in logs) of chosen firm $j$

CEO of choosing firm $i$ is also board chairperson

CEO of choosing firm $i$ tenure years $\mathrm{X}$ total CEO compensation (in logs) of chosen firm $j$

Average number of other board memberships among choosing firm $i \mathrm{X}$ total CEO compensation (in logs) of chosen firm $j$

Number of non-independent board members among choosing firm $i \mathrm{X}$ total CEO compensation (in logs) of chosen firm $j$

Total number of board members among choosing firm $i \mathrm{X}$ total CEO compensation (in logs) of chosen firm $j$

Includes chosen-firm total compensation (in logs)

Includes chosen-firm characteristics

Includes difference between choosing and chosen-firm characteristics Choosing-firm fixed effects

S\&P Index and GICS Industry fixed effects

R-squared

Sample Size

Notes: * significant at $10 \%$; ** significant at $5 \%$; *** significant at $1 \%$

Standard errors, in parentheses, are clustered at the choosing-firm level.

Each observation represents one possible choosing firm and benchmark firm choice combination. All financial measures are lagged one year.

All difference measures are measured in natural logs of the absolute value of the difference between the choosing and potential benchmark firm choice.

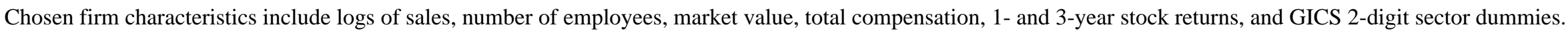

\begin{tabular}{|c|c|c|c|c|c|c|c|}
\hline $\begin{array}{l}0.0009 * * \\
(0.0004)\end{array}$ & $\begin{array}{l}0.0002 \\
(0.0004)\end{array}$ & & & & & $\begin{array}{l}0.0002 \\
(0.0004)\end{array}$ & $\begin{array}{l}0.0000 \\
(0.0005)\end{array}$ \\
\hline \multicolumn{8}{|l|}{$\begin{array}{l}-0.0051^{*} \\
(0.0031)\end{array}$} \\
\hline & & $\begin{array}{l}-0.0001^{* * *} \\
(0.0000)\end{array}$ & & & & $\begin{array}{l}-0.0001^{* *} \\
(0.0000)\end{array}$ & $\begin{array}{l}-0.0000 * \\
(0.0000)\end{array}$ \\
\hline & & & $\begin{array}{l}0.0018 * * * \\
(0.0004)\end{array}$ & & $\begin{array}{l}0.0017 * * * \\
(0.0004)\end{array}$ & $\begin{array}{l}0.0017 * * * \\
(0.0004)\end{array}$ & $\begin{array}{l}0.0016 * * * \\
(0.0004)\end{array}$ \\
\hline & & & & $\begin{array}{l}-0.0003 \\
(0.0002)\end{array}$ & $\begin{array}{l}-0.0001 \\
(0.0002)\end{array}$ & $\begin{array}{l}-0.0001 \\
(0.0002)\end{array}$ & $\begin{array}{l}-0.0002 \\
(0.0002)\end{array}$ \\
\hline & & & & & & & $\begin{array}{l}0.0002 \\
(0.0001)\end{array}$ \\
\hline Yes & Yes & Yes & Yes & Yes & Yes & Yes & Yes \\
\hline Yes & Yes & Yes & Yes & Yes & Yes & Yes & Yes \\
\hline Yes & Yes & Yes & Yes & Yes & Yes & Yes & Yes \\
\hline No & Yes & Yes & Yes & Yes & Yes & Yes & Yes \\
\hline Yes & Yes & Yes & Yes & Yes & Yes & Yes & Yes \\
\hline 0.036 & 0.043 & 0.043 & 0.043 & 0.043 & 0.043 & 0.043 & 0.043 \\
\hline $1,378,259$ & 1,378,259 & $1,362,864$ & $1,332,093$ & 1,332,093 & $1,332,093$ & $1,304,728$ & $1,304,728$ \\
\hline
\end{tabular}


Table 8: Two-Stage-Least-Squares Estimates of the Effect of Others' Compensation

\begin{tabular}{|c|c|c|c|c|c|c|c|c|c|}
\hline \multicolumn{10}{|c|}{ "ependent variable: log of own total CEO compensation; Fiscal Year 2007 (cols. 1-9) and 2008 (cols. 1,7-9) } \\
\hline & 1 & 2 & 3 & 4 & 5 & 6 & 7 & 8 & 9 \\
\hline Specification & OLS & 2SLS & 2SLS & 2SLS & 2SLS & 2SLS & 2SLS & 2SLS with & 2SLS with \\
\hline $\begin{array}{l}\text { Mean total compensation of } \\
\text { benchmark in previous year } \\
\text { (logs) }\end{array}$ & $\begin{array}{l}0.3962 * * * \\
(0.1134)\end{array}$ & $\begin{array}{l}0.4473^{*} \\
(0.2511)\end{array}$ & $\begin{array}{l}0.4871 * * \\
(0.2279)\end{array}$ & $\begin{array}{l}0.4843 \\
(1.1634)\end{array}$ & $\begin{array}{l}0.6426^{*} \\
(0.3304)\end{array}$ & $\begin{array}{l}0.5231^{*} \\
(0.3135)\end{array}$ & $\begin{array}{l}0.4633^{* *} \\
(0.1917)\end{array}$ & $\begin{array}{l}\text { Firm F.E. } \\
0.5613^{* * *} \\
(0.2163)\end{array}$ & $\begin{array}{l}\text { Firm F.E. } \\
0.6327 * * \\
(0.2685)\end{array}$ \\
\hline $\begin{array}{l}\text { Total sales last year (in } \\
\text { logs) }\end{array}$ & $\begin{array}{l}-0.0107 \\
(0.0462)\end{array}$ & $\begin{array}{l}0.0267 \\
(0.0852)\end{array}$ & $\begin{array}{l}0.0186 \\
(0.0811)\end{array}$ & $\begin{array}{l}0.5298 \\
(0.4318)\end{array}$ & $\begin{array}{l}0.0299 \\
(0.1300)\end{array}$ & $\begin{array}{l}0.0463 \\
(0.1254)\end{array}$ & $\begin{array}{l}-0.0228 \\
(0.0543)\end{array}$ & $\begin{array}{l}-0.1987^{* *} \\
(0.1008)\end{array}$ & $\begin{array}{l}-0.2026^{* *} \\
(0.1026)\end{array}$ \\
\hline $\begin{array}{l}\text { Number of employees last } \\
\text { year (1000s) }\end{array}$ & $\begin{array}{l}0.0004 * * \\
(0.0002)\end{array}$ & $\begin{array}{l}0.0003 \\
(0.0003)\end{array}$ & $\begin{array}{l}0.0003 \\
(0.0003)\end{array}$ & $\begin{array}{l}0.0011 \\
(0.0012)\end{array}$ & $\begin{array}{l}0.001 \\
(0.0006)\end{array}$ & $\begin{array}{l}0.001 \\
(0.0006)\end{array}$ & $\begin{array}{l}0.0004 * * \\
(0.0002)\end{array}$ & $\begin{array}{l}0.0003 \\
(0.0011)\end{array}$ & $\begin{array}{l}0.0004 \\
(0.0012)\end{array}$ \\
\hline Assets last year (in logs) & $\begin{array}{l}0.1135^{* *} \\
(0.0508)\end{array}$ & $\begin{array}{l}0.1286 * * \\
(0.0615)\end{array}$ & $\begin{array}{l}0.1263 * * \\
(0.0608)\end{array}$ & $\begin{array}{l}-0.1037 \\
(0.2694)\end{array}$ & $\begin{array}{l}0.1776 \\
(0.1162)\end{array}$ & $\begin{array}{l}0.184 \\
(0.1156)\end{array}$ & $\begin{array}{l}0.1095 * * \\
(0.0532)\end{array}$ & $\begin{array}{l}-0.0164 \\
(0.1218)\end{array}$ & $\begin{array}{l}-0.0258 \\
(0.1275)\end{array}$ \\
\hline $\begin{array}{l}\text { Market value last year (in } \\
\text { logs) }\end{array}$ & $\begin{array}{l}0.0105 \\
(0.0631)\end{array}$ & $\begin{array}{l}-0.0306 \\
(0.0795)\end{array}$ & $\begin{array}{l}-0.035 \\
(0.0813)\end{array}$ & $\begin{array}{l}-0.2818 \\
(0.3952)\end{array}$ & $\begin{array}{l}-0.1787 \\
(0.1520)\end{array}$ & $\begin{array}{l}-0.1635 \\
(0.1554)\end{array}$ & $\begin{array}{l}0.0032 \\
(0.0594)\end{array}$ & $\begin{array}{l}-0.0223 \\
(0.1214)\end{array}$ & $\begin{array}{l}-0.0307 \\
(0.1250)\end{array}$ \\
\hline $\begin{array}{l}\text { 1-year total return to } \\
\text { shareholders }\end{array}$ & $\begin{array}{l}0.0037^{*} \\
(0.0021)\end{array}$ & $\begin{array}{l}0.0078^{* *} \\
(0.0036)\end{array}$ & $\begin{array}{l}0.0078 * * \\
(0.0036)\end{array}$ & $\begin{array}{l}0.017 \\
(0.0117)\end{array}$ & $\begin{array}{l}0.0100^{*} \\
(0.0054)\end{array}$ & $\begin{array}{l}0.0099 * \\
(0.0054)\end{array}$ & $\begin{array}{l}0.0037^{*} \\
(0.0021)\end{array}$ & $\begin{array}{l}0.0006 \\
(0.0009)\end{array}$ & $\begin{array}{l}0.0006 \\
(0.0009)\end{array}$ \\
\hline $\begin{array}{l}\text { 3-year total return to } \\
\text { shareholders }\end{array}$ & $\begin{array}{l}-0.0045 \\
(0.0072)\end{array}$ & $\begin{array}{l}-0.0072 \\
(0.0097)\end{array}$ & $\begin{array}{l}-0.0072 \\
(0.0097)\end{array}$ & $\begin{array}{l}-0.0244 \\
(0.0173)\end{array}$ & $\begin{array}{l}-0.0106 \\
(0.0121)\end{array}$ & $\begin{array}{l}-0.0106 \\
(0.0121)\end{array}$ & $\begin{array}{l}-0.0046 \\
(0.0072)\end{array}$ & $\begin{array}{l}0.0004 \\
(0.0025)\end{array}$ & $\begin{array}{l}0.0003 \\
(0.0026)\end{array}$ \\
\hline Is in the S\&P 500 Index & $\begin{array}{l}0.1576^{* *} \\
(0.0625)\end{array}$ & $\begin{array}{l}0.1337 \\
(0.0826)\end{array}$ & $\begin{array}{l}0.1321 \\
(0.0823)\end{array}$ & $\begin{array}{l}0.1151 \\
(0.1572)\end{array}$ & $\begin{array}{l}0.2279 * * \\
(0.1125)\end{array}$ & $\begin{array}{l}0.2372 * * \\
(0.1106)\end{array}$ & $\begin{array}{l}0.1548 * * \\
(0.0625)\end{array}$ & & \\
\hline CEO's age & $\begin{array}{l}0.0200^{* * *} \\
(0.0066)\end{array}$ & $\begin{array}{l}0.0211^{* *} \\
(0.0094)\end{array}$ & $\begin{array}{l}0.0211^{* *} \\
(0.0094)\end{array}$ & $\begin{array}{l}0.0443^{*} \\
(0.0263)\end{array}$ & $\begin{array}{l}0.021 \\
(0.0132)\end{array}$ & $\begin{array}{l}0.021 \\
(0.0131)\end{array}$ & $\begin{array}{l}0.0198 * * * \\
(0.0067)\end{array}$ & & \\
\hline Is FY 2008 & $\begin{array}{l}-0.1007 \\
(0.0710)\end{array}$ & & & & & & $\begin{array}{l}-0.1021 \\
(0.0705)\end{array}$ & & \\
\hline Sector fixed effects level & 2-digit & 2-digit & 2-digit & 4-digit & 4-digit & 4-digit & 2-digit & & \\
\hline R-squared & 0.19 & 0.21 & 0.21 & 0.15 & 0.11 & 0.12 & 0.19 & & \\
\hline Sample Size & 1304 & 650 & 650 & 315 & 576 & 576 & 1304 & 472 & 472 \\
\hline
\end{tabular}

Panel B- First Stage of the above specifications (the variable instrumented above is mean total compensation of benchmark)

\begin{tabular}{|c|c|c|c|c|c|c|c|c|}
\hline Instrument & & & & & & & & \\
\hline $\begin{array}{l}\text { Average lagged sales } \\
\text { among peers of peers (logs) }\end{array}$ & $\begin{array}{l}0.1944 * * * \\
(0.0207)\end{array}$ & $\begin{array}{l}0.2366^{* * *} \\
(0.0301)\end{array}$ & & & & $\begin{array}{l}0.2196 * * * \\
(0.0204)\end{array}$ & $\begin{array}{l}0.1625^{* * *} \\
(0.0443)\end{array}$ & $\begin{array}{l}0.1927^{* * *} \\
(0.026)\end{array}$ \\
\hline $\begin{array}{l}\text { Average lagged } \\
\text { employment among peers of }\end{array}$ & & $\begin{array}{l}-0.0487 * \\
(0.0280)\end{array}$ & & & & $\begin{array}{l}-0.0588^{* * *} \\
(0.0187)\end{array}$ & $\begin{array}{l}0.0420 \\
(0.0446)\end{array}$ & \\
\hline $\begin{array}{l}\text { Average lagged 1-year } \\
\text { stock return among peers of }\end{array}$ & & $\begin{array}{l}-0.0002^{* *} \\
(0.0001)\end{array}$ & & & & $\begin{array}{l}-0.0001^{* * *} \\
(0.0000)\end{array}$ & $\begin{array}{l}-0.0001^{* * *} \\
(0.0000)\end{array}$ & \\
\hline $\begin{array}{l}\text { Average lagged sales among peers of peers } \\
\text { not in same industry (logs) }+\end{array}$ & & & $\begin{array}{l}0.0839 * * * \\
(0.0284)\end{array}$ & $\begin{array}{l}0.1225^{* * *} \\
(0.0239)\end{array}$ & $\begin{array}{l}0.1856^{* * *} \\
(0.0417)\end{array}$ & & & \\
\hline $\begin{array}{l}\text { Average lagged employment among peers } \\
\text { of peers not in same industry (logs) + }\end{array}$ & & & & & $\begin{array}{l}-0.0701^{*} \\
(0.0409)\end{array}$ & & & \\
\hline $\begin{array}{l}\text { Average lagged 1-year stock return among } \\
\text { peers of peers not in same industry+ }\end{array}$ & & & & & $\begin{array}{l}-0.0001 \\
(0.0001)\end{array}$ & & & \\
\hline $\begin{array}{l}\text { F-statistic for excluded } \\
\text { P-value for the above test }\end{array}$ & $\begin{array}{l}87.55 \\
0.0000\end{array}$ & $\begin{array}{l}36.01 \\
0.0000\end{array}$ & $\begin{array}{l}8.73 \\
0.0037\end{array}$ & $\begin{array}{l}26.13 \\
0.0000\end{array}$ & $\begin{array}{l}10.54 \\
0.0000\end{array}$ & $\begin{array}{l}68.70 \\
0.0000\end{array}$ & $\begin{array}{l}11.11 \\
0.0000\end{array}$ & $\begin{array}{l}26.53 \\
0.0000\end{array}$ \\
\hline R-squared of first stage & 0.74 & 0.75 & 0.73 & 0.69 & 0.69 & 0.72 & 0.14 & 0.12 \\
\hline
\end{tabular}

Notes: * significant at $10 \%$; ** significant at $5 \%$; ${ }^{* * *}$ significant at $1 \%$. Robust standard errors in parentheses.

All financial measures are lagged one year. All specifications include controls for total sales, assets, and number of employees. Sector fixed effects are at the 2-level GICS code or 4-level SIC codes. Columns 8 and 9 exclude all firms for which CEO turnover occurred during the sample years.

+ In column 4, IV excludes all peers-of-peers at the same 2-digit GICS code. In columns 5 and 6, IV excludes peers-of-peers at the same 4digit SIC code. 
Table 9: Reduced-Form and Falsification Tests

\begin{tabular}{|c|c|c|c|c|c|c|}
\hline \multicolumn{7}{|c|}{ OLS; Dependent variable: log of own total CEO compensation (cols } \\
\hline 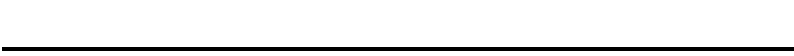 & 1 & 2 & 3 & 4 & 5 & 6 \\
\hline \multirow{2}{*}{$\begin{array}{l}\text { Dependent variable } \\
\text { Mean total sales of peers-of-peers in the previous year } \\
(\$ 1000 \text { s) }\end{array}$} & \multicolumn{3}{|c|}{ Own Pay (in logs) } & \multicolumn{3}{|c|}{ Own Sales (\$) } \\
\hline & $\begin{array}{l}0.0025^{* * *} \\
(0.0009)\end{array}$ & & $\begin{array}{l}0.0027^{*} \\
(0.0016)\end{array}$ & & & \\
\hline $\begin{array}{l}\text { Mean total sales of peers-of-peers in the previous year } \\
\text { excluding those in same industry }(\$ 1000 \mathrm{~s})+\end{array}$ & & $\begin{array}{l}0.0014 * \\
(0.0008)\end{array}$ & & & & \\
\hline $\begin{array}{l}\text { Mean total sales of peers-of-peers in the FOLLOWING } \\
\text { year }(\$ 1000 \text { s) }\end{array}$ & & & $\begin{array}{l}-0.0007 \\
(0.0015)\end{array}$ & & & \\
\hline $\begin{array}{l}\text { Mean total sales of peers-of-peers during the same year } \\
(\$ 1000 \text { s) }\end{array}$ & & & & $\begin{array}{l}-0.0223 \\
(0.0388)\end{array}$ & $\begin{array}{l}-0.0414 \\
(0.0456)\end{array}$ & \\
\hline $\begin{array}{l}\text { Mean total sales of peers-of-peers not in same industry } \\
\text { during the same year }(\$ 1000 \text { s })+\end{array}$ & & & & & & $\begin{array}{l}-0.0095 \\
(0.0393)\end{array}$ \\
\hline Total own firm sales last year (in logs) & $\begin{array}{l}0.0917 \\
(0.0600)\end{array}$ & $\begin{array}{l}0.0717 \\
(0.0668)\end{array}$ & $\begin{array}{l}0.1013 \\
(0.0633)\end{array}$ & & & \\
\hline Number of employees last year (1000s) & $\begin{array}{l}0.0002 \\
(0.0002)\end{array}$ & $\begin{array}{l}0.0003 \\
(0.0003)\end{array}$ & $\begin{array}{l}0.0002 \\
(0.0002)\end{array}$ & $\begin{array}{l}0.1518^{* * *} \\
(0.0247)\end{array}$ & $\begin{array}{l}0.1472 * * * \\
(0.0216)\end{array}$ & $\begin{array}{l}0.1717 * * * \\
(0.0112)\end{array}$ \\
\hline Assets last year (in logs) & $\begin{array}{l}0.1465^{* *} \\
(0.0599)\end{array}$ & $\begin{array}{l}0.1899 * * * \\
(0.0613)\end{array}$ & $\begin{array}{l}0.1552^{* *} \\
(0.0652)\end{array}$ & $\begin{array}{l}7.1548^{* * *} \\
(1.4717)\end{array}$ & $\begin{array}{l}6.9524^{* * *} \\
(1.3392)\end{array}$ & $\begin{array}{l}7.2741^{* * *} \\
(1.5626)\end{array}$ \\
\hline Market value last year (in logs) & $\begin{array}{l}-0.0128 \\
(0.0933)\end{array}$ & $\begin{array}{l}-0.0277 \\
(0.0992)\end{array}$ & $\begin{array}{l}-0.0239 \\
(0.0973)\end{array}$ & $\begin{array}{l}5.6180^{*} \\
(3.4015)\end{array}$ & $\begin{array}{l}7.6682^{*} \\
(4.0344)\end{array}$ & $\begin{array}{l}3.9815 \\
(3.6296)\end{array}$ \\
\hline 1-year total return to shareholders & $\begin{array}{l}0.0075^{*} \\
(0.0039)\end{array}$ & $\begin{array}{l}0.0076^{*} \\
(0.0042)\end{array}$ & $\begin{array}{l}0.0081 * \\
(0.0041)\end{array}$ & $\begin{array}{l}0.0579 \\
(0.0449)\end{array}$ & $\begin{array}{l}-0.0778 \\
(0.0506)\end{array}$ & $\begin{array}{l}0.0605 \\
(0.0461)\end{array}$ \\
\hline 3-year total return to shareholders & $\begin{array}{l}-0.0065 \\
(0.0104)\end{array}$ & $\begin{array}{l}-0.0076 \\
(0.0109)\end{array}$ & $\begin{array}{l}-0.0067 \\
(0.0108)\end{array}$ & $\begin{array}{l}-0.0255 \\
(0.0699)\end{array}$ & $\begin{array}{l}0.0286 \\
(0.0576)\end{array}$ & $\begin{array}{l}-0.03 \\
(0.0761)\end{array}$ \\
\hline Is in the S\&P 500 Index & $\begin{array}{l}0.1481^{*} \\
(0.0843)\end{array}$ & $\begin{array}{l}0.1583^{*} \\
(0.0864)\end{array}$ & $\begin{array}{l}0.1697^{*} \\
(0.0954)\end{array}$ & $\begin{array}{l}-8.4142^{* * *} \\
(2.9476)\end{array}$ & $\begin{array}{l}-11.4075^{* * *} \\
(3.9536)\end{array}$ & $\begin{array}{l}-7.2051^{* *} \\
(3.0929)\end{array}$ \\
\hline CEO's age & $\begin{array}{l}0.0187 * \\
(0.0102)\end{array}$ & $\begin{array}{l}0.0258 * * \\
(0.0122)\end{array}$ & $\begin{array}{l}0.0187 * \\
(0.0108)\end{array}$ & $\begin{array}{l}0.0373 \\
(0.0972)\end{array}$ & $\begin{array}{l}0.0189 \\
(0.1167)\end{array}$ & $\begin{array}{l}0.0872 \\
(0.1091)\end{array}$ \\
\hline CEO's tenure in years & $\begin{array}{l}-0.0085 \\
(0.0061)\end{array}$ & $\begin{array}{l}-0.0053 \\
(0.0067)\end{array}$ & $\begin{array}{l}-0.0091 \\
(0.0063)\end{array}$ & $\begin{array}{l}0.2046^{*} \\
(0.1124)\end{array}$ & $\begin{array}{l}0.1383 \\
(0.1292)\end{array}$ & $\begin{array}{l}0.2711^{* *} \\
(0.1219)\end{array}$ \\
\hline Sector fixed effects & Yes & Yes & Yes & Yes & Yes & Yes \\
\hline Constant & $\begin{array}{l}22.8559 * \\
(11.8913)\end{array}$ & $\begin{array}{l}16.0608 \\
(13.0353)\end{array}$ & $\begin{array}{l}24.1683^{* *} \\
(12.2554)\end{array}$ & $\begin{array}{l}-497.6433^{* *} \\
(235.4921)\end{array}$ & $\begin{array}{l}-371.0347 \\
(273.2502)\end{array}$ & $\begin{array}{l}-623.0446^{* *} \\
(256.0329)\end{array}$ \\
\hline R-squared & 0.21 & 0.19 & 0.20 & 0.61 & 0.56 & 0.64 \\
\hline Sample Size & 637 & 565 & 597 & 637 & 647 & 565 \\
\hline
\end{tabular}

Notes: * significant at $10 \%$; ** significant at $5 \%$; *** significant at $1 \%$

Robust standard errors in parentheses.

+In column 2 and 6, measure excludes all peers-of-peers at the same 4-digit SIC code.

All financial measures are lagged one year unless otherwise noted.

Sector fixed effects are at the 2-level GICS code. 